MARCOS LUCON

\title{
AVALIAÇÃO DO METABOLISMO DOS GLICOSAMINOGLICANOS EM PACIENTES PORTADORES DE CISTITE INTERSTICIAL
}

Tese apresentada à Universidade de São Paulo Faculdade de Medicina para obtenção do título de Doutor em Ciências

Área de concentração: Urologia Orientador: Prof.Dr.Homero Bruschini

(Versão corrigida. Resolução CoPGr 5890, de 20 de dezembro de 2010. A versão original está disponível na Biblioteca FMUSP) 
Dados Internacionais de Catalogação na Publicação (CIP)

Preparada pela Biblioteca da

Faculdade de Medicina da Universidade de São Paulo

Creprodução autorizada pelo autor

Lucon, Marcos

Avaliação do metabolismo dos glicosaminoglicanos em pacientes portadores de cistite intersticial / Marcos Lucon. -- São Paulo, 2012.

Tese(doutorado)--Faculdade de Medicina da Universidade de São Paulo.

Programa de Urologia.

Orientador: Homero Bruschini.

Descritores: 1.Cistite intersticial 2.Glicosaminoglicanas 3.Ácido hialurônico

USP/FM/DBD-391/12 
Dedicatória 
À minha esposa Mariana e aos meus filhos Carolina e João Pedro, pela compreensão e suporte, e por serem a razão pelo qual enfrentamos desafios e aceitamos privações desta vida;

Aos meus pais Ida e Marmo, pelo amor e apoio incondicionais. 
Agradecimentos 


\section{AGRADECIMENTOS}

Ao meu pai, Antonio Marmo Lucon, minha fonte de inspiração, pelo exemplo de vida pessoal, de ética, de dedicação e de perseverança;

Ao Prof. Dr. Homero Bruschini, meu orientador, pelas oportunidades e por sempre ter acreditado na minha capacidade;

Ao Prof. Dr. Miguel Srougi, pelo exemplo e por ter permitido a realização deste trabalho;

Ao Dr. João Roberto M. Martins à Dra. Elsa Yoko Kobayashi, por suas enormes contribuições para a realização deste projeto;

À Profa. Dra. Kátia Ramos Leite, ao Dr. José Carlos Ibanhez Truzzi e ao Dr. Roberto André Soler Mesquita, pela paciência e valiosas sugestões durante a aula de qualificação;

Ao Dr. Neslon Ileo Dias Montellato, Dr. José Alaor de Figueiredo, Dr. Fábio Baracat, Dr. Flávio E. Trigo-Rocha, Dr. Cristiano Mendes Gomes, Dr. Marcelo Hisano, Dr. Ricardo Vita Nunes, Dra. Rosa Maria Cortês Cavalcante e Dr. Zen Mohammed Zammour, pela amizade e contribuições durante a realização desta tese;

Ao Dr. Valter Cassão, pela amizade e por sua participação na execução deste processo;

A todos os Professores, Residentes, Enfermeiros e Funcionários da Disciplina de Urologia do Hospital das Clínicas da Faculdade de Medicina da Universidade de São Paulo, pela minha formação. 


\section{SUMÁRIO}

Lista de abreviaturas, símbolos e siglas

Lista de tabelas

Lista de Figuras

Lista de gráficos

RESUMO

SUMMARY

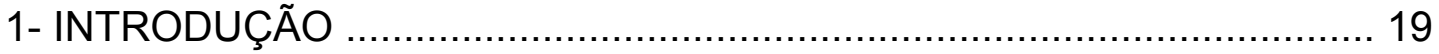

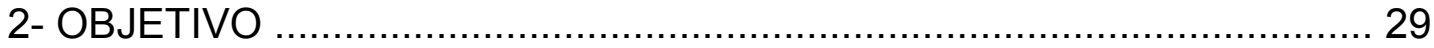

3- CASUÍSTICA E MÉTODOS …....................................................... 30

3.1- Extração de GAG sulfatados e de ácido hialurônico na urina ............... 36

3.2 - Extração dos GAG do tecido ................................................... 38

3.3 - Imunofluorescência dos tecidos ................................................. 38

3.4 - Extração de RNA total e PCR em tempo real ..................................... 39

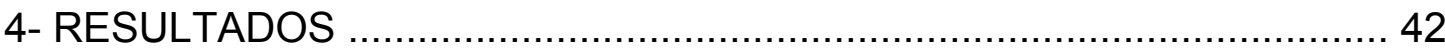

4.1- Extração de GAG sulfatados e de ácido hialurônico na urina ............... 42

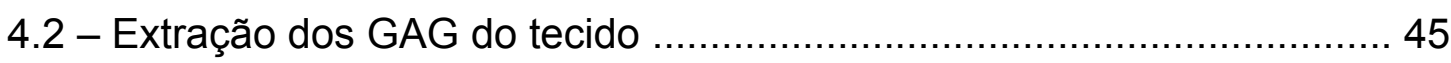

4.3 - Imunofluorescência dos tecidos .................................................. 48

4.4 - Extração de RNA total e PCR em tempo real ................................... 56

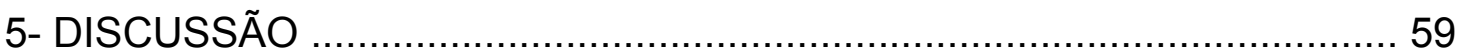

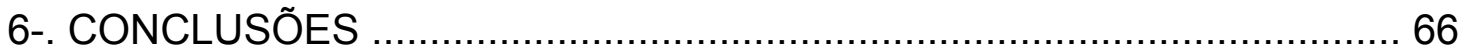

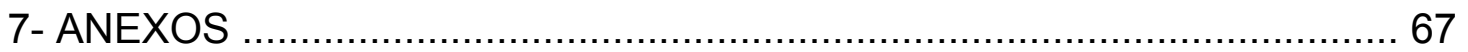

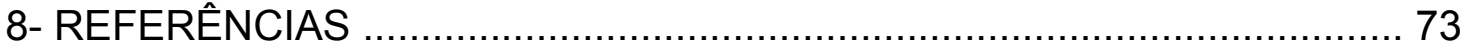


Lista de abreviaturas, símbolos e siglas

BSA bovine serum albumin

PBS phosphade buffered saline

PDA $\quad$ 1,3 diaminopropano acetate

DAPI 4', 6 diamino-2- phenylindole

ELISA enzime-linked immunoabsorbent assay

PCR polimerase chain reaction

nm nanômetro

M molar

kDA quiloDalton 


\section{Lista de Tabelas}

Tabela 1: Critérios do National Institutes of Diabetes, Digestive and Kidney Diseases

Tabela 2: Localização e função dos glicosaminoglicanos

Tabela 3: Características clínicas de pacientes portadoras de cistite intersticial e de controles assintomáticas com incontinência urinária de esforço.

Tabela 4: Sequência dos primers usados nas reações de PCR em tempo real. 


\section{Lista de Figuras}

Figura 1 - A camada hidrofílica de glicosaminoglicanos (GAG) contribui para proteger o urotélio de fatores agressores presentes na urina. Quando lesada, permite o contato dos solutos da urina com o urotélio

Figura 2 - Fotomicrografia demonstrando revestimento epitelial íntegro em uma paciente com incontinência urinária de esforço (A). Em contraste, há erosão urotelial e permeação por células inflamatórias em uma paciente com cistite intersticial $(\mathrm{B})$.

Figura 3 - Fotomicrografia demonstrando intenso infiltrado inflamatório na lâmina própria associado a edema e congestão vascular 40x (A) e 100x (B).

Figura 4- Perfil eletroforético em 1,3-diaminopropano acetato dos glicosaminoglicanos sulfatados obtidos da urina de pacientes com cistite intersticial ( $\mathrm{Cl} 1-7)$ e de pacientes controles portadoras de incontinência urinária de esforço (IUE1-6). CS, condroitim sulfato; DS, dermatam sulfato; HS, heparam sulfato; (+), pólo positivo; (-), pólo negativo; $\mathrm{P}$, padrão de glicosaminoglicanos contendo o equivalente a $5 \mu \mathrm{g}$ em cada banda

Figura 5 - Perfil eletroforético em 1,3-diaminopropano acetato dos glicosaminoglicanos sulfatados obtidos de urotélio de pacientes com cistite intersticial (IC) e de pacientes controles portadoras de incontinência urinária de esforço (IUE). CS, condroitim sulfato; DS, dermatam sulfato; HS, heparam sulfato; (+), pólo positivo; (-), pólo negativo; P, padrão de glicosaminoglicanos contendo o equivalente a $5 \mu \mathrm{g}$ em cada banda. 
Figura 6- Imunofluorescência de para ácido hialurônico (AH), e seu receptor (CD44) na região mais externa do urotélio vesical. Os tecidos das pacientes portadoras de incontinência urinária de esforço (CTR) e de paciente com cistite intersticial (PAT) foram marcados com anticorpos anti-receptor de ácido hialurônico (verde) e com uma proteína de ligação do ácido hialurônico biotinilada (vermelho). Os núcleos foram corados com DAPI (azul). A sobreposição das marcações aparece no painel à direita (Merged). Barra de escala: $50 \mu \mathrm{m}$.

Figura 7- Imunofluorescênciaparaácido hialurônico (AH), e seu receptor (CD44) na região mais interna do urotélio vesical (mucosa/submucosa). Os tecidos controle (CTR) e de paciente com cistite intersticial (PAT) foram marcados com anticorpos anti-receptor de ácido hialurônico (verde) e com uma proteína de ligação do ácido hialurônico biotinilada (vermelho). Os núcleos foram corados com DAPI (azul). A sobreposição das marcações aparece no painel à direita (Merged). Barra de escala: $50 \mu \mathrm{m}$.

Figura 8- Imunofluorescência de TGF- $\beta$ e de decorim na região mais externa dourotélio vesical. Os tecidos das pacientes com incotinência urinária de esforço (CTR) e de três pacientes com cistite intersticial (PAT 1, PAT 2, PAT 3) foram marcados com anticorpos anti-TGF $\beta$ (verde) e anti-decorim (vermelho). Os núcleos foram corados com DAPI (azul). A sobreposição das marcações aparece no painel à direita (Merged). Barra de escala: $50 \mu \mathrm{m}$.

Figura 9- Imunofluorescência de TGF- $\beta$ e de decorim na região mais interna do urotélio vesical (mucosa/submucosa). Os tecidos de uma paciente com incontinência urinária de esforço (CTR) e de três pacientes com cistite intersticial (PAT 1, PAT 2, PAT 3) foram marcados com anticorpos anti-TGF $\beta$ (verde) e anti-decorim (vermelho). Os núcleos foram corados com DAPI (azul). A sobreposição das marcações aparece no painel à direita (Merged). Barra de escala: $50 \mu \mathrm{m}$. 


\section{Lista de Gráficos}

Gráfico 1- Concentração dos glicosaminoglicanos sulfatados urinários de pacientes com cistite intersticial $(\mathrm{Cl})$ e portadoras de incontinência urinária de esforço (IUE). Barras verticais representam os desvios-padrões. Diferença estatisticamente significativa se comparado com IUE $(p<0,05)$.

Gráfico 2 - Proporção relativa dos diferentes glicosaminoglicanos encontrados na urina de pacientes com cistite intersticial (CI) e de portadoras de incontinência urinária de esforço (IUE). CS, condroitim sulfato; DS, dermatam sulfato; HS, heparam sulfato. Barras verticais representam os desvios-padrões. Diferença não significativa na comparação de CS urina-IC versus CS urina-IUE e HS urina-IC versus HS urina-IUE $(p=0,97)$.

Gráfico 3 - Concentração de ácido hialurônico $(\mathrm{AH})$ urinário de pacientes com cistite intersticial (IC) e portadoras de incontinência urinária de esforço (IUE). Barras verticais representam os desvios-padrões. Sem diferença estatisticamente significativa entre os grupos: $p=0,45$.

Gráfico 4 - Concentração dos glicosaminoglicanos sulfatados presentes no urotélio de pacientes com cistite intersticial $(\mathrm{Cl})$ e de pacientes portadoras de incontinência urinária de esforço (IUE). Barras verticais representam os desvios-padrões. A diferença entre os grupos não foi significativa (Mann Whitney, $p=0,62)$.

Gráfico 5 - Proporção relativa de cada glicosaminoglicano encontrado em urotélio de pacientes com cistite intersticial $(\mathrm{Cl})$ e de pacientes controles 
portadoras de incontinência urinária de esforço (CTR). CS, condroitim sulfato; DS, dermatam sulfato; HS, heparam sulfato. Barras verticais representam os desvios-padrões. Diferença não significativa na comparação de CTR-CS+DS versus IC-CS+DS $(p=0,53)$ e também na comparação de CTR-HS versus ICHS $(p=0,53)$.

Gráfico 6 - PCR em tempo real dos genes das sintases do ácido hialurônico: HAS 1. Barras verticais representam os desvios-padrões de três reações para cada gene. Existe diferença significativamente estatística entre os grupos: $\mathrm{p}=0,04$.

Gráfico 7 - PCR em tempo real dos genes das sintases do ácido hialurônico:HAS 2. Barras verticais representam os desvios-padrões de três reações para cada gene. Não existe diferença significativamente estatística entre os grupos: $p=0,11$.

Gráfico 8- PCR em tempo real dos genes das sintases do ácido hialurônico: HAS 3. Barras verticais representam os desvios-padrões de três reações para cada gene. Existe diferença significativamente estatística entre os grupos: $p=0,03$.

Gráfico 9- PCR em tempo real da enzima de degradação do ácido hialurônico - hialuronidase I (Hyal I). Barras verticais representam os desvios-padrões de três reações para cada gene. Existe diferença significativamente estatística entre os grupos: $p=0,03$. 


\section{RESUMO}

Introdução: a cistite intersticial é doença crônica do trato urinário inferior cujos sintomas são: aumento da freqüência urinária, nictúria, dor pélvica ou perineal que piora com a repleção vesical e melhora com a micção. A etiopatogenia não é totalmente conhecida, mas há indícios de que os glicosaminoglicanos e proteoglicanos que revestem o urotélio vesical possam participar da sua gênese. A perda destes componentes protetores facilitaria o contato de íons e solutos presentes na urina com as porções mais profundas do urotélio desencadeando e perpetuando um processo inflamatório local. Para tentar entender seu metabolismo, investigamos o comportamento dos glicosaminoglicanos na urina e no tecido (biópsia do urotélio vesical) de pacientes portadoras de cistite intersticial e de incontinência urinária de esforço genuína.

Casuística e métodos: o perfil e expressão gênica de glicosaminoglicanos no tecido, e o perfil dos glicosaminoglicanos da urina de 11 pacientes com cistite intersticial foram comparados aos de 11 pacientes com incontinência urinária de esforço. A análise estatística foi feita através de teste $T$ e Anova, considerando significativos valores $p<0,05$.

Resultados: verificamos que pacientes com cistite intersticial excretam menor concentração de glicosaminoglicanos na urina do que as portadoras de incontinência urinária de esforço $(0,45 \pm 0,11 \times 0,62 \pm 0,13 \mu \mathrm{g} / \mathrm{mg}$ creatinina, $p<0,05)$, porém sem redução do conteúdo de glicosaminoglicanos no urotélio. $\mathrm{Na}$ imunofluorescência o urotélio de pacientes com cistite intersticial mostrou maior marcação de TGF-beta, decorim (um proteoglicano de condroitim/dermatam sulfato), fibronectina e de ácido hialurônico. Foi identificada menor expressão gênica (PCR em tempo real) das sintases e uma hialuronidase do ácido hialurônico no urotélio das cistites intersticiais.

Conclusão: a combinação desses resultados sugere que os glicosaminoglicanos podem estar relacionados ao processo contínuo de inflamação e remodelamento do urotélio disfuncional presente na cistite 
intersticial. O estudo da expressão gênica pode representar uma altenativa para o entendimento da doença. 


\section{SUMMARY}

Introduction: interstitial cystitis is a chronic disease of the lower urinary tract whose symptoms are: increased urinary frequency, nocturia, perineal or pelvic pain that worses with bladder filling and improves with urination. The pathogenesis is not fully known, but there is evidence that proteoglycans and glycosaminoglycans lining the bladder urothelium can participate in its genesis. The loss of these protective compounds facilitate the contact of ions and solutes in the urine with deeper portions of bladder wall triggering and perpetuating a local inflammatory process. We investigated GAG behavior in urine and tissue (biopsy of bladder urothelium) of patients with IC/PBS and genuine stress urinary incontinence (SUI) in an attempt to better understand its metabolism.

Patients and Methods: gene expression and glycosaminoglycans profile in tissue, and glycosaminoglycans profile in urine of 11 patients with interstitial cystitis were compared to 11 patients with pure urinary stress incontinence. Statistical analysis were performed using t Student test and Anova, considering significant when $p<0,05$.

Results: patients with interstitial cystitis excreted lower concentration of glycosaminoglycans in urine when compared to those with pure urinary stress incontinence (respectively $0.45 \pm 0.11 \times 0.62 \pm 0.13 \mathrm{mg} / \mathrm{mg}$ creatinine, $\mathrm{p}<0.05$ ). However, there was no reduction of the content of glycosaminoglycans in the urothelium of both patients. The immunofluorescence study showed that patients with interstitial cystitis had a stronger staining of TGF-beta, decorin (a proteoglycan of chondroitin/dermatan sulfate), fibronectin and hyaluronic acid. We were able to indentify by real-time PCR lower gene expression of hyaluronic acid synthases and hyaluronidase in the urothelium of patients with interstitial cystitis.

Conclusion: the results suggest that glycosaminoglycans may be related to the ongoing process of inflammation and remodeling of the dysfunctional urothelium 
that is present in the interstitial cystitis. The study of the gene expression may represent an alternative to understand the disease. 


\section{Introdução}

A cistite intersticial é doença do trato urinário inferior caracterizada por dor, pressão ou desconforto percebidos como relacionados à bexiga, acompanhados de aumento da freqüência urinária e noctúria, na ausência de infecção urinária e outros doenças identificáveis (Hanno, Burks et al. 2011). Ocorre mais frequentemente em mulheres ao redor dos 40-50 anos de idade. A doença tem caráter crônico, superior a semanas ou meses, duração esta que varia conforme o critério adotado. A história geralmente longa e variável, levando os pacientes a diferentes serviços médicos e, consequentemente, a várias formas de tratamento. Costuma impor prejuízo à qualidade de vida dos pacientes. O diagnóstico da doença é de exclusão, quando afastadas outras doenças que possuem sintomas semelhantes, não havendo consenso sobre os critérios definitivos (Webster and Brennan 1998, Hanno, Landis et al. 1999, Hanno and Sant 2001, Sant and Hanno 2001, Hanno and Dmochowski 2009).

Historicamente a cistite intersticial era entendida como uma doença da bexiga. No século 19 Joseph Parrish descreveu 3 casos de pacientes com sintomas refratários do trato urinário inferior que se assemelhavam à litíase vesical, mas cuja etiologia não fora identificada (apud ABRAMS, 2009, p.1461) (Hanno P 2009). Esse mesmo autor passou a usar o termo "tix doloureux", que originalmente fora criado para designar uma irritação neurológica da bexiga produzindo dor e desconforto sem causa específica. Após 50 anos, Skene definiu a cistite intersticial como uma inflamação que destrói parcial ou totalmente a membrana mucosa da bexiga, atingindo sua parede (apud ABRAMS, 2009, p.1462)(Hanno P 2009). Em 1915 Hunner a descreveu como uma forma particular de úlcera vesical (úlcera de Hunner) cujo diagnóstico depende da resistência aos tratamentos empregados nos pacientes que apresentavam freqüência urinária e espasmos vesicais intensos (apud ABRAMS, 2009, p1462)(Hanno P 2009). Foi apenas em 1978 que o diagnóstico deixou de ser órgão-específico e passou a ser baseado nos sintomas, conforme proposto por Messing e Stamey.(Messing and Stamey 1978, Hanno, Nordling et al. 2008). Posteriormente, os critérios aceitos para 


\section{fins de pesquisa passaram a ser os do National Institutes of Diabetes, Digestive and Kidney Diseases (Hanno, Landis et al. 1999) (Tabela 1).}

Tabela 1:Critérios do National Institutes of Diabetes, Digestive and Kidney Diseases

\begin{tabular}{|c|c|}
\hline CRITÉRIOS NECESSÁRIOS & CRITÉRIOS QUE EXCLUEM CISTITE INTERSTICIAL \\
\hline \multirow{7}{*}{$\begin{array}{l}\text { Glomerulações ou úlcera de Hunner à cistoscopia. As } \\
\text { glomerulações devem ocorrer após distensão vesical, } \\
\text { sob anestesia, sob pressão de } 80 \text { a } 100 \text { cm } \mathrm{H}_{2} \mathrm{O} \text {, por } 1 \text { a } \\
2 \text { minutos. A bexiga deve ser distendida por até duas } \\
\text { vezes antes da avaliação. As glomerulações devem ser } \\
\text { difusas (presentes em pelo menos } 3 \text { quadrantes da } \\
\text { bexiga) e deve haver no mínimo } 10 \text { glomerulações por } \\
\text { quadrante. Estas não devem encontrar-se no trajeto do } \\
\text { cistoscópio, já que o contato do aparelho pode produzir }\end{array}$} & $\begin{array}{l}\text { Capacidade vesical maior que } 350 \text { cc à cistometria com } \\
\text { gás ou líquido, com o paciente acordado.. }\end{array}$ \\
\hline & $\begin{array}{l}\text { Ausência de desejo miccional intenso com enchimento } \\
\text { vesical de } 1200 \text { cc de gás ou } 150 \text { cc de líquido durante a } \\
\text { cistometria, com velocidade de enchimento de } 30 \text { a } 100 \\
\qquad \text { cc por minuto }\end{array}$ \\
\hline & $\begin{array}{c}\text { Contrações involuntárias fásicas durante a cistometria } \\
\text { com velocidade de enchimento citada }\end{array}$ \\
\hline & Duração de sintomas menor que 9 meses \\
\hline & Ausência de noctúria \\
\hline & $\begin{array}{l}\text { Alívio dos sintomas com o uso de antimicrobianos, } \\
\text { antissépticos urinários, anticolinérgicos ou } \\
\text { antiespasmódicos }\end{array}$ \\
\hline & $\begin{array}{l}\text { Frequência urinária, enquanto acordado, menor que } 8 \\
\qquad \text { vezes ao dia }\end{array}$ \\
\hline \multirow{11}{*}{ dor referida à bexiga ou urgência urinária } & $\begin{array}{l}\text { Diagnóstico de cistite bacteriana ou prostatite nos últimos } \\
\qquad 3 \text { meses }\end{array}$ \\
\hline & Litíase vesical ou ureteral \\
\hline & Herpes genital ativa \\
\hline & Câncer uterino, cervical, vaginal ou uretral \\
\hline & Divertículo uretral \\
\hline & Cistite por ciclofosfamida ou outro agente químico \\
\hline & Cistite tuberculosa \\
\hline & Cistite por radiação \\
\hline & Tumores malignos ou benignos vesicais \\
\hline & Vaginite \\
\hline & Idade menor que 18 anos \\
\hline
\end{tabular}


Com tamanha variação na definição da doença, outras nomenclaturas apareceram ao longo do tempo. A mais recente é síndrome da bexiga dolorosa, assim descrita porque o diagnóstico da doença é eminentemente clínico, baseado em sintomas específicos e na exclusão de outras doenças. Entretanto, o nome cistite intersticial não foi abandonado, sendo reservado por alguns autores para os casos de alterações cistoscópicas e histopatológicas, e por motivos de seguro médico (Abrams, Cardozo et al. 2002, van de Merwe, Nordling et al. 2008). Dessa forma, o termo cistite intersticial será usado neste manuscrito, representando as duas formas em conjunto.

A prevalência é variável em função das diferentes definições da doença: desde 52 a 197 casos por 100.000 mulheres, e 41 casos para cada 100.000 homens. A relação mulher-homem é 8:1 (Curhan, Speizer et al. 1999, Clemens, Meenan et al. 2005, Forrest and Moldwin 2008).

A fisiopatologia da doença ainda é incerta. As teorias propostas incluem aumento da permeabilidade urotelial (Parsons, Lilly et al. 1991, Parsons, Greenberger et al. 1998),infecção (Fall, Johansson et al. 1985), auto-imunidade (Theoharides and Sant 2005), déficit de regeneração epitelial vesical (Keay and Warren 1998, Keay, Kleinberg et al. 2000), ativação neurogênica (Hohenfellner, Nunes et al. 1992) (Hohenfellner, Nunes et al. 1992, Pang, Marchand et al. 1995), ativação mastocitária (Lynes, Flynn et al. 1987, Theoharides, Kempuraj et al. 2001) e causas de ordem psiquiátrica (Gillenwater and Wein 1988). A etiologia da cistite intersticial pode ser ainda multifatorial, com diferentes eventos que levam a um mesmo quadro clínico final.

Pesquisas mais recentes sugeriram a disfunção urotelial como fator etiológico da cistite intersticial. Esta disfunção teria como principal fator causal o déficit de regeneração do urotélio, levando a uma resposta inflamatória crônica e ativação neuronal local. Keay e cols. fizeram importantes descobertas neste campo, através da identificação do fator antiproliferativo (APF) na urina de pacientes com intersticial. Seu mecanismo de ação na regeneração epitelial envolve a inibição do fator de crescimento epidérmico ligante de heparina (HBEGF), um fator de crescimento que atua na replicação celular de diferentes epitélios (Keay, Kleinberg et al. 2000). 
Outra hipótese associada à doença é o aumento da permeabilidade do epitélio vesical. O epitélio vesical dos mamíferos apresenta uma das menores taxas de permeabilidade entre os vários tipos de membranas biológicas. Esta propriedade é mantida por um complexo mecanismo de defesa, situado na membrana especializada das umbrella cells. Complexos juncionais de alta resistência, as tight junctions mantêm a impermeabilidade intercelular, através do bloqueio do fluxo de íons. Na membrana apical encontra-se uma família de proteínas de membrana, as uroplaquinas, que conferem alta impermeabilidade trans epitelial à água e pequenos solutos. Adicionalmente, uma densa camada de glicosaminoglicanos reveste superficialmente toda essa estrutura. Acreditase que qualquer alteração nesta barreira de impermeabilidade promovida pelos glicosaminoglicanos permita a infiltração de componentes da urina nas camadas celulares subjacentes, o que leva a subsequente inflamação (Lilly and Parsons 1990, Parsons, Lilly et al. 1991, Parsons 2007). Figura 1.

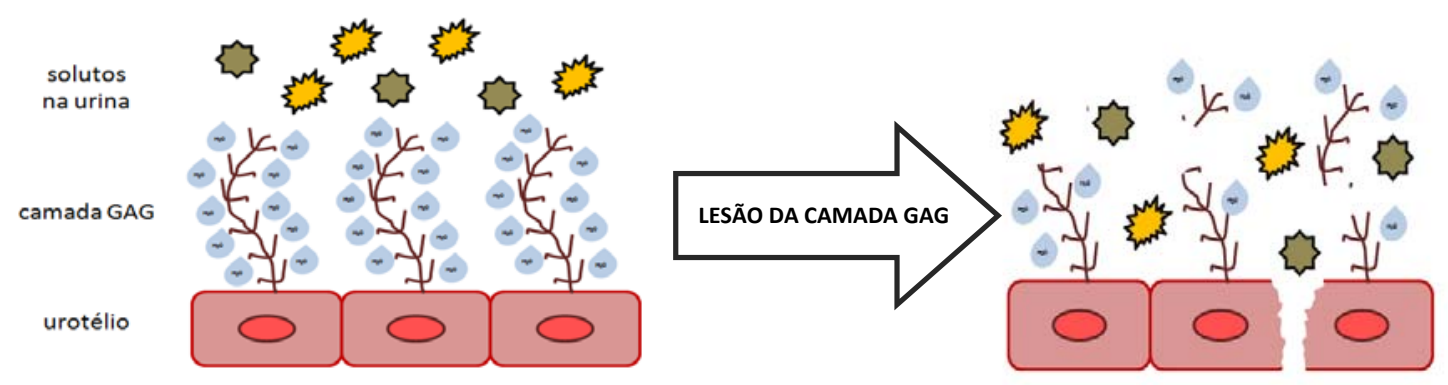

Figura 1 - A camada hidrofílica de glicosaminoglicanos (GAG) contribui para proteger o urotélio de fatores agressores presentes na urina. Quando lesada, permite o contato dos solutos da urina com o urotélio. Modificado de: Parsons C.L. The role of the urinary epithelium in the pathogenesis of interstiitical cystitisi/prostatitis. urethritis. Urology 2007; 69 (4A): 9-16.

Os glicosaminoglicanos são polímeros lineares de açúcares, constituídos por unidades dissacarídicas repetitivas, compostas por uma hexosamina (glucosamina ou galactosamina) e um açúcar não nitrogenado (ácido Dglucurônico, ácido L-idurônico ou D-galactose), unidos entre si por ligações glicosídicas. Devido aos grupamentos carboxílicos e sulfatos, estes polímeros possuem uma alta densidade de cargas negativas, o que lhes confere a grande 
capacidade de reter água (Esko 1991), contribuindo para formar uma camada protetora ao urotélio (Brimacombe and Stacey 1964). Os glicosaminoglicanos diferem entre si quanto ao tipo de hexosamina e açúcar não nitrogenado, quanto ao grau de sulfatação e à posição em que são sulfatados, bem como quanto ao tipo de ligação glicosídica inter e intra-dissacarídica (Mathews 1975). Todos os glicaminoglicanos com exceção do ácido hialurônico ocorrem nos tecidos ligados covalentemente a um esqueleto protéico, formando, assim, macromoléculas denominadas proteoglicanos (Evered 1989, Esko 1991).

Os principais glicosaminoglicanos encontrados nos tecidos animais são: condroitim sulfato, dermatam sulfato, heparam sulfato, heparina, queratam sulfato e ácido hialurônico. As funções dos glicosaminoglicanos são determinadas de acordo com o tecido e com as características próprias de cada composto, ou seja, a conformação estrutural e a densidade e distribuição da carga negativa. Tabela 2.

O ácido hialurônico é o único que não ocorre sob a forma de um proteoglicano, pois não está ligado à proteína de forma covalente. $O$ ácido hialurônico está presente em grande quantidade nos fluidos animais, tais como humor vítreo, líquido sinovial, líquido amniótico, e em diversos tecidos e órgãos como cordão umbilical, músculo, cérebro e rim (Dahl, Hopwood et al. 1983, Laurent and Fraser 1986). Na bexiga, ele predomina no tecido conjuntivo subjacente à mucosa e entre as camadas de músculo liso (Laurent, Hellstrom et al. 1995). A maioria das células sintetiza ácido hialurônico em algum estágio de sua vida. Este glicosaminoglicano tem sido relacionado com a indução da agregação celular em diferentes tipos celulares e parece estar implicado também com a proliferação, migração e adesão celular (Fraser, Laurent et al. 1997). 
Tabela 2:Localização e função dos glicosaminoglicanos

\begin{tabular}{|c|c|c|}
\hline GAG & Localização & Função \\
\hline Heparam Sulfato & $\begin{array}{l}\text { Em todos os tecidos. Superfície } \\
\text { celular, matriz extracelular e } \\
\text { membrana basal. }\end{array}$ & $\begin{array}{l}\text { Molécula de adesão e e } \\
\text { reconhecimento celular. (Dietrich, } \\
\text { Sampaio et al. 1977) Papel na } \\
\text { divisão celular. (Dietrich, Sampaio } \\
\text { et al. 1977, Dietrich 1984, } \\
\text { Porcionatto, Pinto et al. 1994, } \\
\text { Porcionatto, Moreira et al. 1998, } \\
\text { Franco, Rocha et al. 2001) }\end{array}$ \\
\hline $\begin{array}{l}\text { Condroitim 4- } \\
\text { ou 6- Sulfato }\end{array}$ & $\begin{array}{l}\text { Matriz de tecidos conjuntivos, } \\
\text { cartilagens, ossos, vasos sangüíneos. } \\
\text { (Mourao, Rozenfeld et al. 1976, } \\
\text { Dietrich, Sampaio et al. 1977, } \\
\text { Michelacci, Mourao et al. 1979, } \\
\text { Dietrich 1984, Knudson and Knudson } \\
\text { 2001) Matriz de tecidos embrionários e } \\
\text { tumorais. (Sampaio, Dietrich et al. } \\
\text { 1977, Sampaio and Dietrich 1981, De } \\
\text { Klerk, Lee et al. 1984, Martins, } \\
\text { Gadelha et al. 2000, Berto, Oba et al. } \\
\text { 2001, Oba-Shinjo, Berto et al. 2003) }\end{array}$ & $\begin{array}{l}\text { Papel no crescimento e } \\
\text { ossificação (4-sulfato). (Mourao, } \\
\text { Rozenfeld et al. 1976, Michelacci, } \\
\text { Mourao et al. 1979, Dietrich 1984, } \\
\text { Knudson and Knudson 2001) } \\
\text { Proliferação celular. (Dietrich, } \\
\text { Schibuola et al. 1978, Dietrich } \\
\text { 1984, Huang and Ives 1987, } \\
\text { Dietrich, Martins et al. 1993, } \\
\text { Ramanathan, Wilkemeyer et al. } \\
\text { 1996) }\end{array}$ \\
\hline Dermatam Sulfato & $\begin{array}{l}\text { Predominantemente em tecidos } \\
\text { conjuntivos densos, intestinos, pele e } \\
\text { tendão. (Dietrich, Sampaio et al. 1977, } \\
\text { Dietrich 1984, Poblacion and } \\
\text { Michelacci 1986, Scott 1992, Scott } \\
\text { 2001) }\end{array}$ & $\begin{array}{l}\text { Relacionada com a organização, } \\
\text { velocidade de deposição e } \\
\text { manutenção das fibrilas de } \\
\text { colágeno. (Sampaio, Bayliss et al. } \\
\text { 1988, Scott 1992, Scott 2001) }\end{array}$ \\
\hline Ácido hialurônico & $\begin{array}{l}\text { Tecidos conjuntivos, cordão umbilical, } \\
\text { líquidos sinovial e aminiótico, ascites } \\
\text { (Sampaio, Bayliss et al. 1988, } \\
\text { Nogueira, Chehter et al. 1994), matriz } \\
\text { extracelular, humor vítreo, e } \\
\text { cartilagem. (Dahl, Hopwood et al. } \\
\text { 1983, Laurent, Hellstrom et al. 1995) }\end{array}$ & $\begin{array}{l}\text { Lubrifica e protege as articulações, } \\
\text { retém água na matriz, interage } \\
\text { com outros PGs. }\end{array}$ \\
\hline Heparina & $\begin{array}{l}\text { Distribuição irregular. Mastócitos, } \\
\text { pulmão, pele e intestinos de adultos. } \\
\text { Exclusivamente em tecidos } \\
\text { hematopoiéticos em tecidos fetais. } \\
\text { (Nader, Straus et al. 1982, Nader, } \\
\text { Ferreira et al. 1984, Nader, Pinhal et } \\
\text { al. 2001) }\end{array}$ & $\begin{array}{l}\text { Papel biológico possivelmente } \\
\text { associado com defesa do } \\
\text { organismo. Papel farmacológico: } \\
\text { potente anticoagulante e } \\
\text { antitrombótico. (Nader, Straus et } \\
\text { al. 1982, Nader, Ferreira et al. } \\
\text { 1984, Avraham, Stevens et al. } \\
\text { 1989, Kjellen, Pettersson et al. } \\
\text { 1989, Nader, Pinhal et al. 2001, } \\
\text { Opal, Kessler et al. 2002) }\end{array}$ \\
\hline Queratam Sulfato I & $\begin{array}{l}\text { Estroma da córnea. (Scott 1992, } \\
\text { Soriano, Campos et al. 2000, Scott } \\
\text { 2001) }\end{array}$ & $\begin{array}{l}\text { Confere transparência óptica à } \\
\text { córnea. }\end{array}$ \\
\hline Queratam Sulfato II & $\begin{array}{l}\text { Cartilagem articular adulta. (Mourao, } \\
\text { Rozenfeld et al. 1976, Michelacci, } \\
\text { Mourao et al. 1979, Sampaio and } \\
\text { Dietrich 1981) }\end{array}$ & Processos de crescimento. \\
\hline
\end{tabular}


Os proteoglicanos são compostos de alta massa molecular formados por um esqueleto protéico ao qual se ligam de forma covalente cadeias de glicosaminoglicanos e oligossacarídeos $\mathrm{N}$ - e/ou O- ligados (Thonar and Sweet 1979, Lohmander, De Luca et al. 1980, Nilsson, De Luca et al. 1982). Eles estão presentes na matriz extracelular, na membrana basal, na superfície celular e também intracelularmente, em grânulos secretórios. A atividade biológica de cada proteoglicano depende das propriedades do seu esqueleto proteico, da estrutura química do glicosaminoglicano ligado e da sua localização celular. Os proteoglicanos atuam como organizadores de tecidos, influenciam o crescimento celular e a maturação de tecidos especializados, têm um importante papel como filtro biológico, modulam a atividade de determinados fatores de crescimento, regulam a fibrilogênese de colágeno e afetam o crescimento e invasão tumoral.

A partir da década de 70, Parsons e cols (Lilly and Parsons 1990) iniciaram estudos sobre a relação dos glicosaminoglicanos com o urotélio. Evidenciaram que os mesmos representam uma barreira contra a adesão bacteriana, cristais, proteínas e íons aos epitélios adjacentes (Parsons, Greenspan et al. 1975, Parsons, Greenspan et al. 1977, Parsons, Danielson et al. 1985, Lilly and Parsons 1990). Ensaios que neutralizaram sua ação, como a instilação de sulfato de protamina intra-vesical, demonstraram aumento na permeabilidade do urotélio à uréia, cálcio e água, sendo esta alteração revertida com a administração tópica de glicosaminoglicanos exógenos (Parsons, Stauffer et al. 1980). Posteriormente, ficou comprovado que apenas a lesão urotelial não é suficiente para iniciar esse processo na cistite intersticial (Soler, Bruschini et al. 2008). Em modelos animais de cistite induzida por sulfato de protamina, comparou-se seu efeito nas bexigas de ratos nefrectomizados e não nefrectomizados. As alterações histológicas nos animais nefrectomizados foram muito inferiores àquelas dos não operados, concluindo os autores então que a presença de urina foi necessária para desencadear a cascata inflamatória.

Os conceitos inseridos por Parsons à fisiopatologia da cistite intersticial foram amplamente difundidos em urologia, culminando com o desenvolvimento de novas terapias, as chamadas terapias de reposição superficial de 
glicosaminoglicanos e a tentativa de se identificar níveis urinários de glicosaminoglicanos como marcadores da cistite intersticial. As terapias de reposição de glicosaminoglicanos utilizam compostos sintéticos que, teoricamente, aumentariam a sua concentração no urotélio. O pentosan polissulfato é medicação de uso oral aprovada pela Food and Drug Administration para o tratamento da cistite intersticial, nos Estados Unidos (Parsons, Schmidt et al. 1983). Heparina e ácido hialurônico são medicações intravesicais com o mesmo objetivo de fortalecer a barreira urotélial (Morales, Emerson et al. 1997, Nickel, Downey et al. 1998). A utilização de tais terapias que se originou da teoria proposta por Parsons constituem, ainda, tratamentos empíricos e discutíveis, já que o seu mecanismo de ação não foi totalmente elucidado.

Baseados ainda na teoria proposta do defeito na camada de glicosaminoglicanos como um fator causal para a cistite intersticial, estudos foram conduzidos com o objetivo de reproduzir a suposta anormalidade urotelial e correlacioná-la com níveis de glicosaminoglicanos urinários. Soler e cols (Soler, Bruschini et al. 2008) induziram lesão urotelial através de sulfato de protamina em modelo animal e encontraram aumento de glicosaminoglicanos. Hurst e cols (Hurst, Parsons et al. 1993) demonstraram por imumohistoquímica um déficit de condroitim sulfato na superfície luminal e subjacente à camada de células basais em biópsias vesicais de pacientes com cistite intersticial. Além disso, verificaram que níveis urinários de glicosaminoglicanos estariam relacionados à deficiência urotelial e, portanto, níveis reduzidos se associariam com menor concentração local de glicosaminoglicanos no epitélio vesical. No entanto, outros estudos não encontraram o mesmo padrão de glicosaminoglianos no tecido e ácido hialurônico na urina de pacientes com cistite intersticial (Hurst, Parsons et al. 1993, Nickel, Emerson et al. 1993, Akcay and Konukoglu 1999, Wei, Politano et al. 2000). Lokeshwar e cols (Lokeshwar, Selzer et al. 2005, Lokeshwar, Selzer et al. 2006) relataram níveis elevados de glicosaminoglicanos urinários totais, aferidos através da concentração de ácido urônico, em pacientes com cistite intersticial grave. Soler e cols (Soler, Bruschini et al. 2008) demonstraram que a excreção 
urinária de glicosaminoglicanos e ácido hialurônico após a indução de cistite intersticial ocorre em picos distintos.

Assim os resultados da literatura ainda são variáveis e ainda não se encontrou um padrão de excreção de glicosaminoglicanos nos pacientes com cistite intersticial. Os métodos utilizados nos diversos trabalhos podem ajudar a explicar tais diferenças. É possível que kits diversos utilizados nas dosagens laboratoriais exerçam alguma influência nos resultados. Pode-se supor ainda que condições de coleta e armazenamento também tenham algum efeito adicional. Vale ressaltar, no entanto, que a própria doença é controversa, a começar pela sua definição. Dessa forma, é importante mencionar que os estudos podem representar apenas momentos pontuais da mesma cistite intersticial, refletindo fases iniciais ou tardias, mais ou menos sintomáticas. Dentre outras possíveis influências, vale destacar o papel da variação hormonal das mulheres. Maroclo et al mostraram que em mulheres saudáveis existe maior excreção urinária de glicosaminoclicanos na fase pré ovulatória(Maroclo, Pereira et al. 2005). Nosso grupo mostrou, como já foi dito, que a evolução da doença pode interferir no resultado dos glicosaminoglicanos, como por exemplo, na excreção urinária de glicocaminoglicanos em picos diferentes a partir da instilação do sulfato de protamina em modelos animais (Soler, Bruschini et al. 2008). Fomos também capazes de demonstrar a necessidade da presença de urina para provocar as alterações histológicas (Soler, Bruschini et al. 2008), mas não conseguimos definir se o perfil dos glicosaminoglicanos corresponderia uma reação à agressão ou se corresponderia à reparação do urotélio. Fica exposto assim, que conhecimento da cistite intersticial ainda é insuficiente para compreendê-la de forma plena. Mesmo tendo contribuído de alguma forma com esse entendimento, nosso grupo também não conseguiu traduzir os achados dos níveis urinários e teciduais dos glicosaminoglicanos em estudos em animais, para fisiopatologia da doença. Por outro lado, poucas são as informações relativas à expressão de genes desses compostos, cuja principal publicação foi de Lokeswhar et cols (Lokeshwar, Selzer et al. 2005, Lokeshwar, Selzer et al. 2006). Nesse sentido, e como já foi colocado por Hanno e cols (Hanno, Lin et al. 2010), pesquisas envolvendo novos mecanismos são necessárias para completar o processo de 
compreensão da doença:"Recommendations for future research pathways are suggested". 


\section{2- Objetivo}

Avaliar o metabolismo dos glicosaminoglicanos na urina e tecido (por biópsia de urotélio vesical) de portadores de cistite intersticial, comparando-os com os de pacientes portadoras de incontinência urinária de esforço genuína. 


\section{Casuística e métodos}

Casuística

As pacientes foram oriundas do Ambulatório de Urologia do Hospital das Clínicas da Faculdade de Medicina da USP (HC-FMUSP) durante o período de Fevereiro de 2009 à Janeiro de 2012. O protocolo de pesquisa foi aprovado pela Comissão de Ética para Análise de Projetos de Pesquisa do HCFUMSP CAPPesq, sob número 0504/08. Todos os indivíduos envolvidos assinaram Termo de Consentimento Livre e Esclarecido concordando em participar do estudo.

Foram 2 grupos de pacientes: um com cistite intersticial, um segundo grupo com incontinência de esforço genuína e portanto com bexigas supostamente normais.

O grupo de cistite intersticial incluiu 11 pacientes do sexo feminino com idade igual ou maior que 18 anos, com urina estéril e com diagnóstico segundo critérios do National Institutes of Diabetes, Digestive and Kidney Diseases (anexo 1) (Hanno, Landis et al. 1999), exceto pelas alterações cistoscópicas. Foram excluídas lactantes, antecedente de cistoscopia nos últimos 3 meses, antecedente ou estar fazendo uso de droga investigacional nos últimos 30 dias, as que tenham recebido qualquer terapia intra-vesical nos últimos 6 meses, doença neurológica que potencialmente afetasse a função vesical e história de ter sido submetida à procedimentos que gerem seqüela vesical. Todas as pacientes completaram questionário clínico avaliando idade, data do início dos sintomas, doenças co-existentes, gravidade dos sintomas, tipos de tratamento pregresso e índice de qualidade de vida (anexos 2) (O'Leary, Sant et al. 1997). Foram então submetidas à cistoscopia iniciando-se pela coleta de urina seguida da biópsia vesical. Logo após fez-se a hidrodistensão vesical com $80 \mathrm{cmH} 2 \mathrm{O}$ por 3 minutos com finalidade terapêutica (Forrest and Moldwin 2008). Graduou-se o aspecto da mucosa em O- normal, I- petéquias em pelo 
menos 2 quadrantes, II- equimoses, III- sangramento difuso da mucosa e IVrotura da mucosa(Hanno P 2009). Todas as pacientes haviam sido submetidas à estudo urodinâmico com intervalo mínimo de 3 meses antes da coleta de material. A idade foi 26 a 73 anos, com mediana de 48 anos.

No grupo de incontinência urinária de esforço foram incluídas 11 pacientes com perdas urinárias comprovadas em estudo urodinâmico também com intervalo mínimo de 3 meses antecedendo a coleta de material. Foram excluídas aquelas com infecção urinária e outras queixas ou sintomas miccionais. Estas pacientes foram submetidas a tratamento cirúrgico através de sling retropúbico em que é mandatória a cistoscopia para diagnosticar eventuais perfurações durante a cirurgia. No momento da cistoscopia foi colhida amostra de urina e então feita a biópsia vesicsal. Este grupo foi composto de 11 pacientes com idade de 50 a 79 anos, mediana de 64 anos, e foi considerado como grupo controle.

As amostras de urina foram colhidas no momento da cirurgia para análise de urina tipo I e nova urocultura e acondicionadas em frasco plástico estéril com meio específico, conforme descrito abaixo. Foram encaminhadas à Disciplina de Biologia Molecular da Universidade Federal de São Paulo Unifesp (Universidade Federal de São Paulo) para análise dos glicosaminoglicanos, da expressão gênica, e de creatinina urinária. Ao Laboratório de Investigação Médica da Divisão de Urologia (LIM 55) da FMUSP foram encaminhadas também amostras das biópsias vesicais para análise histológica. 
Esquema do estudo:

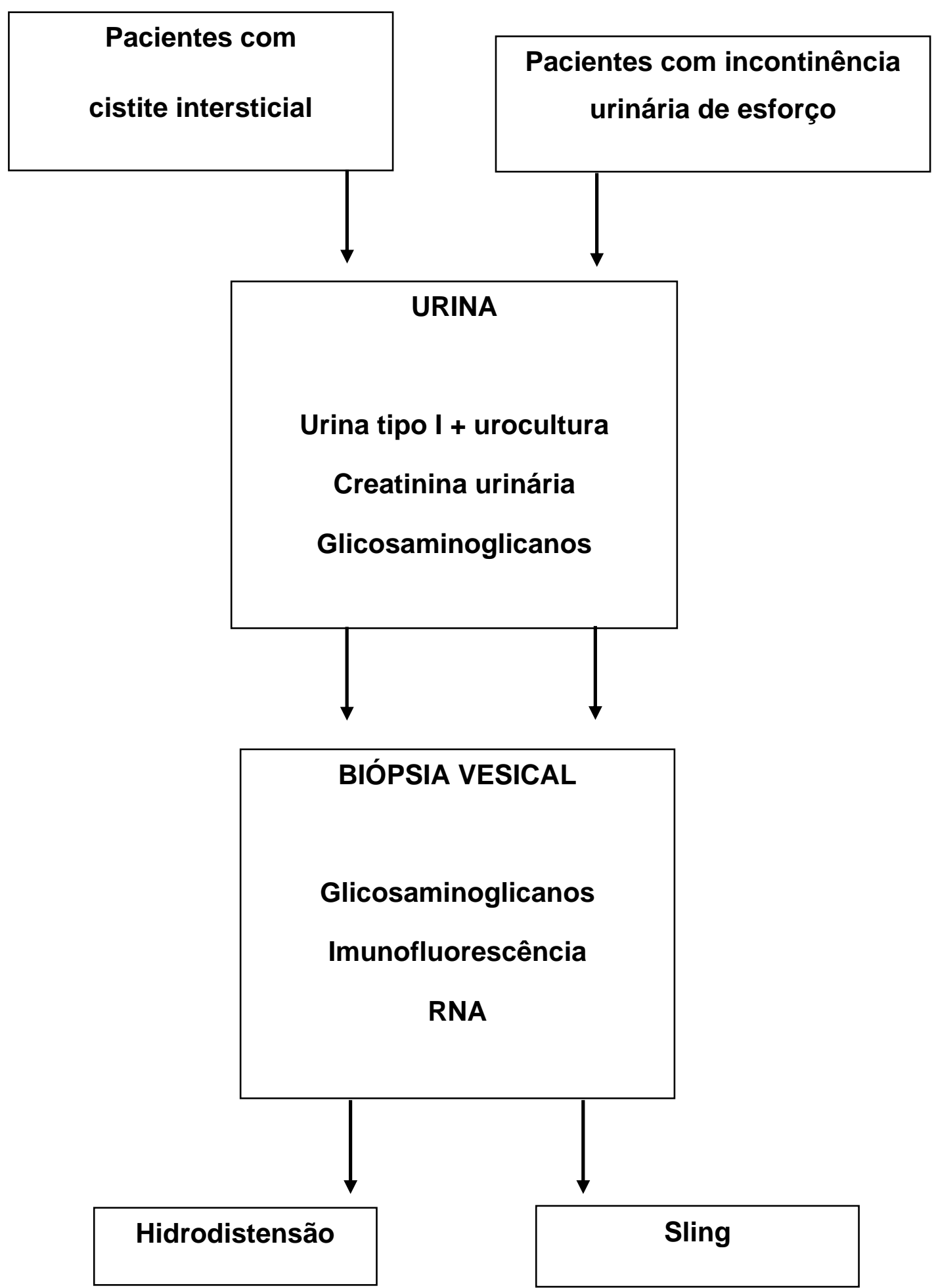


A Tabela 3 resume os dados clínicos das pacientes. A idade média do grupo $\mathrm{Cl}$ foi estatisticamente menor do que a do grupo controle $(p=0,015)$. Uma paciente foi excluída por apresentar trato urinário. As pacientes apresentavam cistite intersticial cuja mediana da escola de sintomas foi 16 e de incômodo foi 10. No estudo urodinâmico, nenhuma paciente incluída apresentou hiperatividade detrusora. As pacientes portadoras de cistite intersticial apresentaram menor capacidade cistométrica média $(227 \pm 83,00 \mathrm{ml} \times 391,67 \pm$ $93,04, p<0,001)$ quando comparadas às portadoras de incontinência urinária de esforço.

Uma paciente com cistite intersticial foi excluída por apresentar de cultura de urina colhida no ato cirúrgico positiva. 
Tabela 3- Características clínicas de pacientes portadoras de cistite intersticial e de controles assintomáticas com incontinência urinária de esforço.

\begin{tabular}{|c|c|c|c|c|c|}
\hline $\begin{array}{l}\text { Idade } \\
\text { (anos) }\end{array}$ & Sintomas clínicos & $\begin{array}{c}\text { Escala de } \\
\text { sintomas } \\
(0-23)\end{array}$ & $\begin{array}{c}\text { Escala de } \\
\text { incômodo } \\
(0-12)\end{array}$ & $\begin{array}{c}\text { Uro } \\
\text { Cultura }\end{array}$ & $\begin{array}{l}\text { Mucosa } \\
\text { pós } \\
\text { distensão }\end{array}$ \\
\hline 27 & Dor vesical, nictúria & 17 & 10 & Negativa & Grau I \\
\hline 40 & Dor vesical, nictúria & 15 & 11 & Negativa & Grau 0 \\
\hline 53 & $\begin{array}{c}\text { Dor supra púbica, } \\
\text { nictúria }\end{array}$ & 0 & 0 & Negativa & Grau III \\
\hline $64^{*}$ & Nictúria & 9 & 8 & Positiva & Grau 0 \\
\hline 65 & $\begin{array}{l}\text { Dor vesical e anal, } \\
\text { nictúria, dispareunia }\end{array}$ & 17 & 9 & Negativa & Grau 0 \\
\hline 73 & $\begin{array}{c}\text { Dor vesical, dispareunia, } \\
\text { polaciúria }\end{array}$ & 14 & 8 & Negativa & Grau I \\
\hline 43 & $\begin{array}{c}\text { Dor vesical, dispareunia, } \\
\text { nictúria }\end{array}$ & 21 & 12 & Negativa & Grau I \\
\hline 27 & Dor vesical, nictúria & 15 & 12 & Negativa & Grau 0 \\
\hline 57 & $\begin{array}{c}\text { Dor supra púbica, } \\
\text { dispareunia, polaciúria, } \\
\text { nictúria }\end{array}$ & 20 & 12 & Negativa & Grau 0 \\
\hline 26 & $\begin{array}{c}\text { Dor supra púbica, } \\
\text { dispareunia, polaciúria, } \\
\text { nictúria }\end{array}$ & 20 & 11 & Negativa & Grau III \\
\hline 48 & $\begin{array}{c}\text { Dor supra púbica, } \\
\text { dispareunia, polaciúria, } \\
\text { nictúria }\end{array}$ & NA & NA & Negativa & Grau I \\
\hline Mediana & e idade: 48 (26-73) & $\begin{array}{l}\text { Mediana } \\
16(0-21)\end{array}$ & $\begin{array}{l}\text { Mediana } \\
\text { 10(0-12) }\end{array}$ & & \\
\hline 68 & Incontinência & - & - & Negativa & \\
\hline 53 & Incontinência & - & - & Negativa & \\
\hline 71 & Incontinência & - & - & Negativa & \\
\hline 64 & Incontinência & - & - & Negativa & \\
\hline 61 & Incontinência & - & - & Negativa & \\
\hline 59 & Incontinência & - & - & Negativa & \\
\hline 64 & Incontinência & - & - & Negativa & \\
\hline 50 & Incontinência & - & - & Negativa & \\
\hline 79 & Incontinência & - & - & Negativa & \\
\hline 66 & Incontinência & - & - & Negativa & \\
\hline 54 & Incontinência & - & - & Negativa & \\
\hline \multicolumn{6}{|c|}{ Medidana de idade: 64 (50-79) } \\
\hline
\end{tabular}

* paciente excluída da análise 
A análise histológica considerou alterações no urotélio de revestimento e na lâmina própria. Para a avaliação urotelial foram analisados erosão epitelial, ulceração, metaplasia escamosa e permeação epitelial por células inflamatórias. Para a lâmina própria avaliamos a presença de edema, hemorragia intersticial, congestão vascular e a presença de infiltrado inflamatório, sendo essas características graduadas em leve, moderada ou grave.

Nas controles as alterações epiteliais estavam ausentes e naquelas com cistite intersticial erosão e permeação por células inflamatórias foram os achados mais importantes (figura 2). No interstício do grupo controle havia edema e ectasia vascular. Nas cistites existiu discreto a moderado infiltrado inflamatório com predomínio de linfócitos que formaram agregados havendo, ainda, raros plasmócitos e eosinófilos. Associado existiu edema, ectasia vascular e hemorragia intersticial (figura 3).

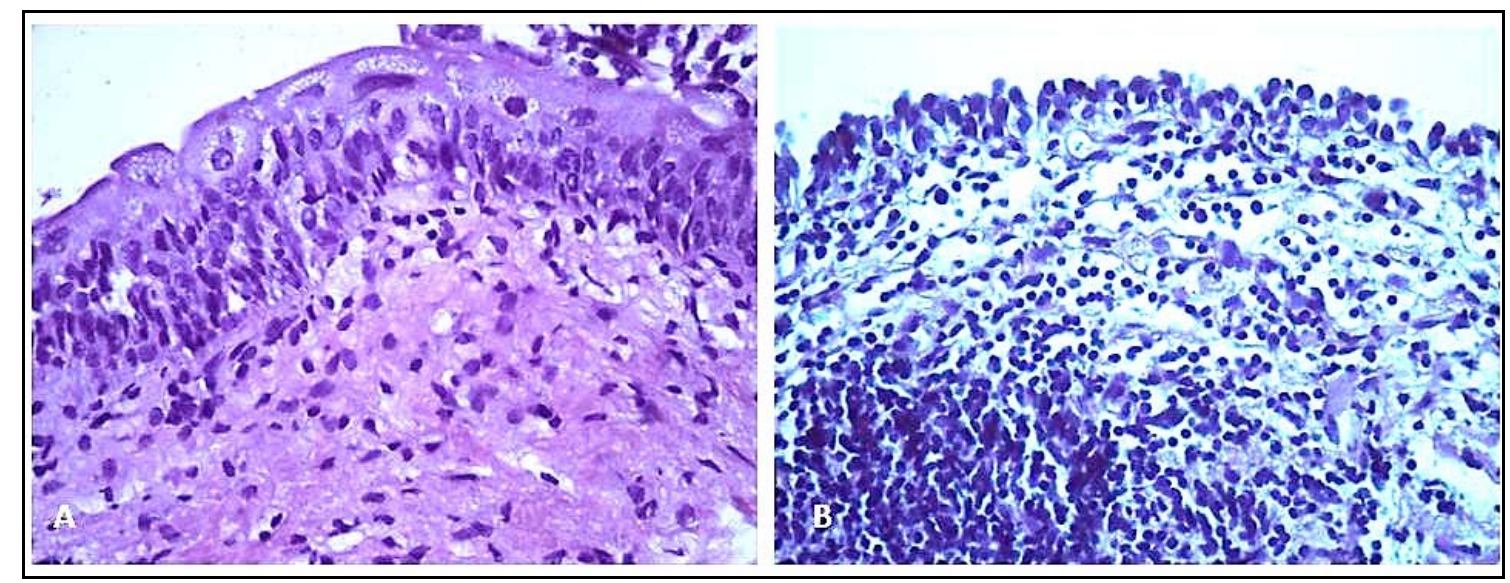

Figura 2 - Fotomicrografia demonstrando revestimento epitelial íntegro em uma paciente com incontinência urinária de esforço (A). Em contraste, há erosão urotelial e permeação do epitélio por células inflamatórias em uma paciente com cistite intersticial (B) 


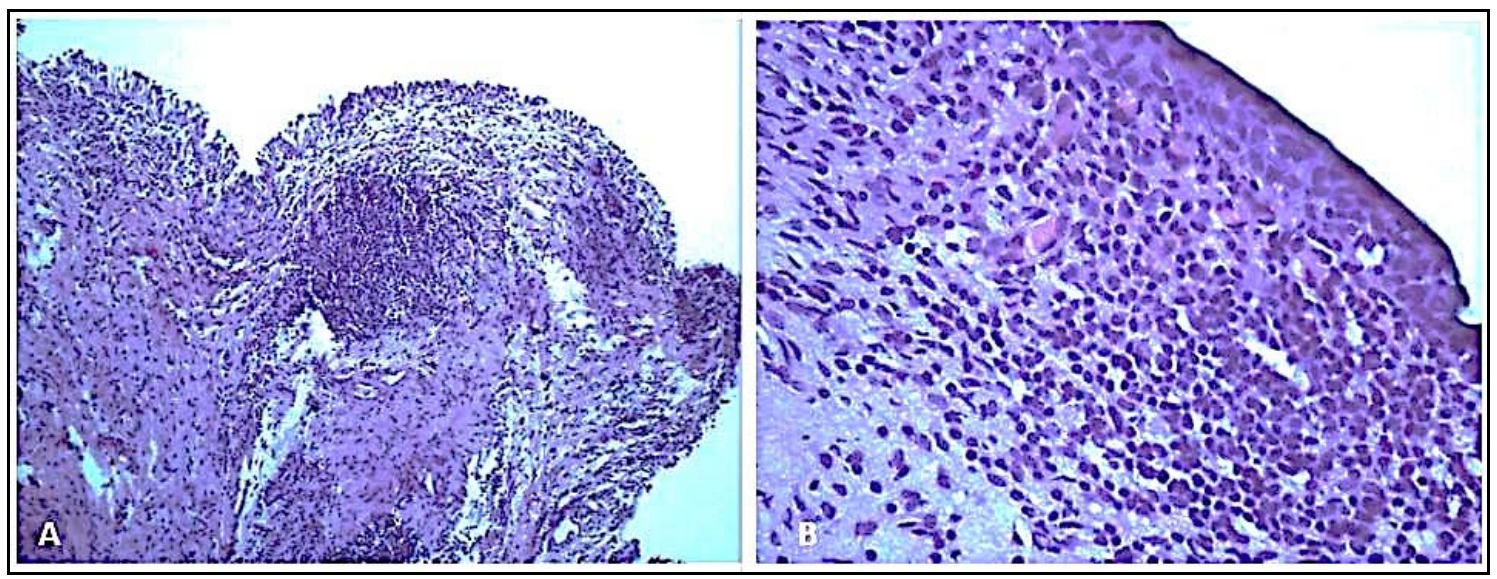

Figura 3 - Fotomicrografia demonstrando infiltrado inflamatório intenso na lâmina própria associado a edema e congestão vascular 40x (A) e 100x (B).

Método

3.1 -Extração e quantificação de glicosaminoglicanos sulfatados e de ácido hialurônico na urina

Para análise dos glicosaminoglicanos sulfatados, $8 \mathrm{~mL}$ de cada urina foram concentrados e lavados duas vezes com água destilada ( $8 \mathrm{~mL})$ em tubos de concentração Amicon Ultra de 3kDa (Millipore Corporation, Carrigtwohill, Ireland) até o volume final de $20 \mu \mathrm{L}$. Cinco $\mu \mathrm{L}$ da solução obtida bem como $5 \mu \mathrm{L}$ de uma mistura padrão de glicosaminoglicanos (contendo $1 \mathrm{mg} / \mathrm{mL}$ de condroitim sulfato, dermatam sulfato e heparam sulfato, todos da Seikagaku Kogyo Co., Tokyo, Japan) foram submetidos à eletroforese, 100V por 1 hora, em agarose no tampão 1,3 diaminopropano acetato 0,05M, pH 9,0 (PDA). O ponto de partida da eletroforese corresponde ao pólo negativo uma vez que em função da carga negativa dos glicosaminoglicanos eles migram em direção ao pólo positivo. Assim, nesse sistema é possível discriminar, por ordem decrescente de mobilidade eletroforética, três principais glicosaminoglicanos: o condroitim sulfato (CS), o dermatam sulfato (DS) e o heparan sulfato (HS), respectivamente. Finalmente, os glicosaminoglicanos foram precipitados no gel pela adição de brometo de cetiltrimetilamônio (CETAVLON, Sigma-Aldrich, Saint Louis, MO) $0,1 \%$ por um período mínimo de duas horas, a temperatura 
ambiente. Após secagem sob calor e ventilação, o gel foi corado com solução de azul de toluidina $0,1 \%$ em ácido acético $1 \%$ e etanol $50 \%$, por cerca de 15 minutos. $O$ excesso do corante foi removido com solução de ácido acético $1 \%$ em etanol $50 \%$. A quantificação dos glicosaminoglicanos presentes nas diferentes amostras foi feita por densitometria óptica A595nm no equipamento QuickScan (Helena Laboratories, Seiko, Japan). O conteúdo dos glicosaminoglicanos presentes nas diferentes amostras foram expressos $\mu \mathrm{g} / \mathrm{mg}$ creatinina.

A análise do ácido hialurônico foi realizada conforme método previamente descrito (Martins et al., 2003 e 2004). Em resumo, $100 \mu \mathrm{L} /$ poço de cada urina (diluídas 1:2 no tampão de ensaio Tris- $\mathrm{HCl} 0,05 \mathrm{M}, \mathrm{pH} 7,75+\mathrm{BSA}$ $1 \%)$ e também a mesma quantidade de uma curva padrão $(0-1000 \mathrm{ng} / \mathrm{mL})$ de ácido hialurônicode cordão umbilical humano (Sigma-Aldrich, Saint Louis, MO) foram aplicados, em triplicatas, em placas de ELISA (Perkin-Elmer Life Sciences- WallacOy, Turku, Finland) previamente revestidas com uma proteína de ligação do ácido hialurônico extraída de cartilagem nasal bovina (Martins et al., 2003). Após 12 horas de incubação a $4^{\circ} \mathrm{C}$, as placas foram lavadas 6 vezes com tampão de lavagem (Tris-HCl0,05M, pH 7,75) e seguiu-se a adição da proteína de ligação do ácido hialurônico marcada com biotina $(1 \mathrm{mg} / \mathrm{mL})$ diluída em tampão de ensaio. As placas foram então agitadas a temperatura ambiente por 2 horas e lavadas 12 vezes com o tampão de lavagem para remoção da proteína biotinilada não complexada ao ácido hialurônico retido na placa. Por fim, a presença da biotina na placa foi determinada pela adição de $100 \mu \mathrm{L} /$ poço de estreptavidina marcada com európio (Perkin-Elmer Life SciencesWallacOy, Turku, Finland) diluída 1:10.000 em tampão de ensaio, 30 minutos, sob agitação. Para medir a fluorescência emitida pelo európio, 200 $\mu \mathrm{L}$ de uma solução de Enhancement (Perkin-Elmer Life Sciences- WallacOy, Turku, Finland) foram adicionados em cada poço e a leitura feita no equipamento Victor 2 (Perkin-Elmer Life Sciences- WallacOy, Turku, Finland). Os valores de ácido hialurônicoforam expressos em $\mathrm{ng} / \mathrm{mg}$ de creatinina. 


\section{2 - Extração dos glicosaminoglicanos do tecido}

Amostras de tecidos de 6 pacientes portadoras de cistite intersticial e 7 portadoras de incontinência urinária de esforço foram processadas bioquimicamente e analisadas quanto ao conteúdo dos glicosaminoglicanos sulfatados, conforme já descrito (Dietrich and Dietrich 1976, Martins, Gadelha et al. 2000, Perosa, Porcionatto et al. 2002, Martins, Passerotti et al. 2003, Martins, Furlanetto et al. 2004). Em resumo, as amostras de tecido vesical foram picotadas em 10 volumes de acetona para remoção de água e lipídeos. $O$ pó cetônico obtido foi então submetido à proteólise com a enzima maxatase $4 \mathrm{mg} / \mathrm{ml}$ (Biocon do Brasil Industrial, Rio de Janeiro, Brasil) em tampão TrisHCL50mM, NaCl1M, pH 8,0, "overnight". Peptídeos e ácidos nucléicos foram precipitados com ácido tricloroacético $90 \%$, e os glicosaminoglicanos precipitados do sobrenadante pela adição de metanol. Após incubação a $-20^{\circ} \mathrm{C}$, 18 horas, o precipitado contendo os glicosaminoglicanos foi seco e ressuspenso em água destilada ( $1 \mu \mathrm{L}$ para cada $\mathrm{mg}$ de tecido seco). A identificação dos diferentes glicosaminoglicanos obtidos pelo procedimento acima foi feita por eletroforese conforme descrito anteriormente (item 3.1). Os valores foram expressos em $\mu \mathrm{g} / \mathrm{mg}$ de pó seco.

\section{3 - Imunofluorescência dos tecidos}

As amostras dos tecidos de pacientes com cistite intersticial $(n=6)$ e portadoras de incontinência urinária de esforço $(n=4)$ foram lavadas em PBS e imediatamente fixadas em solução de paraformaldeído $4 \%$ por 2 horas em temperatura ambiente. A seguir os fragmentos foram incluídos em meio de congelamento para fluorescência Tissue freezing medium - TissueTek (Sakura Finetek USA, Inc., Torrance, CA, USA) e congelados em gelo seco e isopentano, e mantidos em freezer $-70^{\circ} \mathrm{C}$.

A seguir, foram feitos cortes em criostato (Leica, Wetzlar, Germany) com espessura de aproximadamente $5 \mu \mathrm{m}$, os quais foram colocados em lâminas silanizadas. 
Para as reações de imunofluorescência os cortes foram lavados 5 vezes com PBS e 1 vez com PBS contendo glicina 0,1M. Nessa etapa foram feitas três combinações de anticorpos, em lâminas separadas, para análise: 1) antiCD44 (Santa Cruz Bioechnology Inc., CA, USA) X sonda biotinilada da proteína de ligação do ácido hialurônico (preparada em nosso laboratório conforme Martins et al., 2003); 2) anti-decorim (Seikagaku, Japan) $X$ anti-TGF- $\beta$ (Santa Cruz Bioechnology Inc., CA, USA); 3) anti-sindecam (Santa Cruz Bioechnology Inc., CA, USA) X anti-fibronectina (Santa Cruz Bioechnology Inc., CA, USA). As lâminas foram incubadas com os anticorpos mencionados acima e também com a proteína de ligação ao ácido hialurônico biotinilada, por 2 horas a temperatura ambiente. Ao final da incubação, as lâminas foram lavadas por 3 vezes em PBS, e agora incubadas com anticorpo secundário ou estreptavidina conjugados com marcador fluorescente AlexaFluor ${ }^{\mathrm{TM}} 488$ ou 594 ou 546 ou 630 ou 430 (o número corresponde ao comprimento de onda de excitação do fluoróforo conjugado) diluído 1:300 em PBS. Após 30 minutos de incubação, as lâminas foram lavadas 5 vezes em PBS e o núcleo foi marcado com DAPI (4'6diamidino-2-fenilindole, dihidrocloride - marcação em azul) 1:10.000 em PBS contendo $0,01 \%$ de saponina (detergente que permeabiliza a membrana celular) por 30 minutos. A seguir, as lâminas foram lavadas 5 vezes em PBS, lavadas uma vez mais em água ultrapura e, finalmente, montadas com lamínulas histológicas em Fluormont G (Electron Microscopy Sciences, Hatfield, PA, USA). As lâminas foram observadas e analisadas em microscópio de fluorescência (Nikon Eclipse, TE300 e TE800, Tokyo, Japan) e em microscópio confocal (LSM500 meta - Carl Zeiss, Germany). Os controles para os experimentos de imunomarcação foram realizados omitindo-se o anticorpo primário.

\section{4 - Extração de RNA total e PCR em tempo real}

Amostras do urotélio de 6 pacientes com cisite intersticial e de 5 pacientes com incontinência urinária de esforço foram processadas para extração de RNA conforme descrito a seguir. Após congelamento em nitrogênio líquido os tecidos foram pulverizados para a extração de RNA total utilizando o reagente Trizol $^{\circledR}($ Invitrogen, Life Technologies, New York, EUA), seguindo o 
protocolo do fabricante. Para cada $5 \mathrm{mg}$ de tecido foram usados $500 \mu \mathrm{L}$ do reagente Trizol adicionados diretamente sobre 0 tecido previamente pulverizado, seguido de incubação por 5 minutos, a temperatura ambiente. A seguir, adicionaram-se 100 $\mu \mathrm{L}$ de clorofórmio para cada volume de Trizol. Após agitação vigorosa e incubação a temperatura ambiente por 2 a 3 minutos, a solução foi centrifugada e a fase aquosa, contendo o RNA total, separada. Para precipitar o RNA foram adicionados $250 \mu \mathrm{L}$ de isopropanol, seguido de incubação por 10 minutos a temperatura ambiente e centrifugação por 20 minutos a $4^{\circ} \mathrm{C}$. O pellet de RNA total obtido foi ressuspenso com etanol $75 \%$ em água tratada com dietilpirocarbonato (DEPC) no mesmo volume de Trizol. Novamente, a solução foi centrifugada a $4^{\circ} \mathrm{C}$ e o sobrenadante descartado. $\mathrm{O}$ RNA total precipitado foi seco a $4^{\circ} \mathrm{C}$ e então ressuspenso em $30 \mu \mathrm{L}$ de água destilada tratada com DEPC.

Após extração do RNA total do tecido vesical de cada amostra, o cDNA foi obtido através da reação da transcriptase reversa, utilizando Kit Promegalmprom II TM Reverse Transcriptase (PROMEGA Corporation, Madison, WI, EUA). Inicialmente $2 \mu \mathrm{g}$ de RNA total, determinado por absorção a $260 \mathrm{~nm}$, foram utilizados para obtenção de cDNA. A reação de RT foi realizada conforme especificado pelo fabricante do kit e utilizado $0,5 \mu \mathrm{g}$ de OligodT (IDT, Coralville, IA, EUA) com o seguinte protocolo: anelamento $\left(25^{\circ} \mathrm{C}, 5 \mathrm{~min}\right)$, extensão $\left(42^{\circ} \mathrm{C}, 60 \mathrm{~min}\right)$ e inativação da transcriptase reversa $\left(70^{\circ} \mathrm{C}, 15 \mathrm{~min}\right)$.

O cDNA assim obtido foi submetido a reações de PCR em tempo real usando o equipamento 7500 Real-Time PCR System (Applied Biosystems, Warrington, Reino Unido). Foram avaliadas a expressão gênica das três sintases do ácido hialurônico (HAS 1, 2 e 3), da hialuronidase I (HYAL I) e do gene ribossomal S29 (RPS29). As reações foram realizadas utilizando-se o kit Sybr Green Master Mix da Applied Biosystems (Warrington, England), e os resultados analisados com auxílio do software do próprio equipamento. As reações foram feitas em triplicatas para cada gene. As seqüências dos oligonucleotídeos usados estão representadas abaixo: 
Tabela 4- Sequência dos primers usados nas reações de PCR em tempo real.

\begin{tabular}{|c|c|}
\hline Gene & Sequência dos primers \\
\hline \multirow{2}{*}{$18 S$} & Sense: $5^{\prime}$ cat cctgcgtctggacctgg $3^{\prime}$ \\
\hline & Antisense: $5^{\prime}$ ggcagctca tag ctcttc $3^{\prime}$ \\
\hline \multirow{2}{*}{ HAS 1} & Sense: $5^{\prime}$ gtgagtggctgtacaacg cg $3^{\prime}$ \\
\hline & Antisense: $5^{\prime}$ gag ggacgtagt tag cgg c $3^{\prime}$ \\
\hline \multirow{2}{*}{ HAS 2} & Sense: $5^{\prime}$ tgg cat cacacctcatcatc $3^{\prime}$ \\
\hline & Antisense: $5^{\prime}$ accaattgcgttacgtgttg $3^{\prime}$ \\
\hline \multirow{2}{*}{ HAS 3} & Sense: $5^{\prime}$ ttggctgtgtgcagtgtattagt $3^{\prime}$ \\
\hline & Antisense: 5' ggtctctgt gag gcacttgg 3' \\
\hline \multirow{2}{*}{ HYAL I } & Sense: $5^{\prime}$ taa ccc tgc cag tttctc cat cca 3' \\
\hline & Antisense: 5' agc cag ggtagcatcgacatttga 3' \\
\hline
\end{tabular}




\section{Resultados}

4.1 - Glicosaminoglicanos sulfatados e ácido hialurônico na urina

Considerando que a perda da camada de glicosaminoglicanos dos urotélios tem sido relacionada com a etiopatogenia da cistite intersticial e que essa queda poderia influenciar nos níveis urinários desses compostos dosamos os glicosaminoglicanos na urina. A Figura 4 mostra o perfil eletroforético dos diferentes glicosaminoglicanos presentes na urina em amostra isolada dessas pacientes. Nela observamos que nos subgrupos de doenças há dois glicosaminoglicanos urinários predominantes, CS e HS, sendo que CS ocorre em maior proporção em todas as amostras.

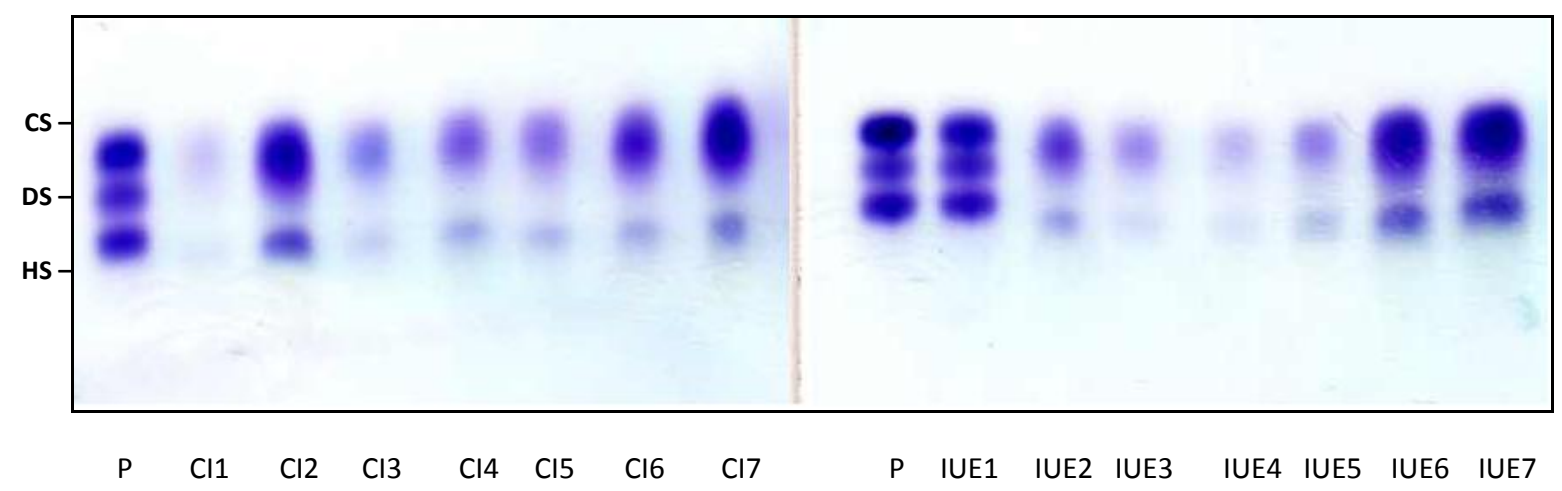

Figura 4- Perfil eletroforético em 1,3-diaminopropano acetato dos glicosaminoglicanos sulfatados obtidos da urina de pacientes com cistite intersticial (Cl1-7) e de pacientes controles portadoras de incontinência urinária de esforço (IUE1-6). CS, condroitim sulfato; DS, dermatam sulfato; HS, heparam sulfato; $(+)$, pólo positivo; (-), pólo negativo; $\mathrm{P}$, padrão de glicosaminoglicanos contendo o equivalente a $5 \mu \mathrm{g}$ em cada banda

Ao comparar a concentração dos glicosaminoglicanos sulfatados totais na urina encontramos uma diminuição estatisticamente significativa $(p<0,05)$ no grupo das cistites intersticiais $(0,45 \pm 0,11 \mu \mathrm{g} / \mathrm{mg}$ creatinina) se comparada a 
concentração de glicosaminoglicanos urinários no grupo de incontinência urinária $(0,62 \pm 0,13 \mu \mathrm{g} / \mathrm{mg}$ creatinina). Gráfico 1.

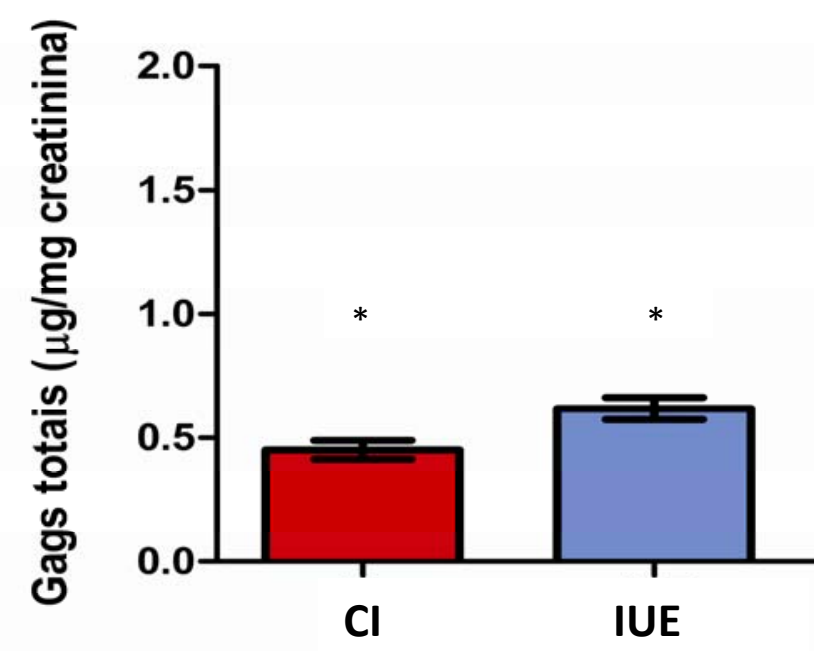

Gráfico 1- Concentração dos glicosaminoglicanos sulfatados urinários de pacientes com cistite intersticial $(\mathrm{Cl})$ e portadoras de incontinência urinária de esforço (IUE). Barras verticais representam os desvios-padrões. Diferença estatisticamente significativa se comparado com IUE.

Para avaliar se essa redução ocorria de forma seletiva, analisamos a proporção de cada glicosaminoglicano. Como mostrado na Gráfico 2, vemos que a porcentagem dos diferentes glicosaminoglicanos encontrada na urina dos grupos foi semelhante, portanto a diminuição observada foi uniforme para todos os compostos presentes na urina. 


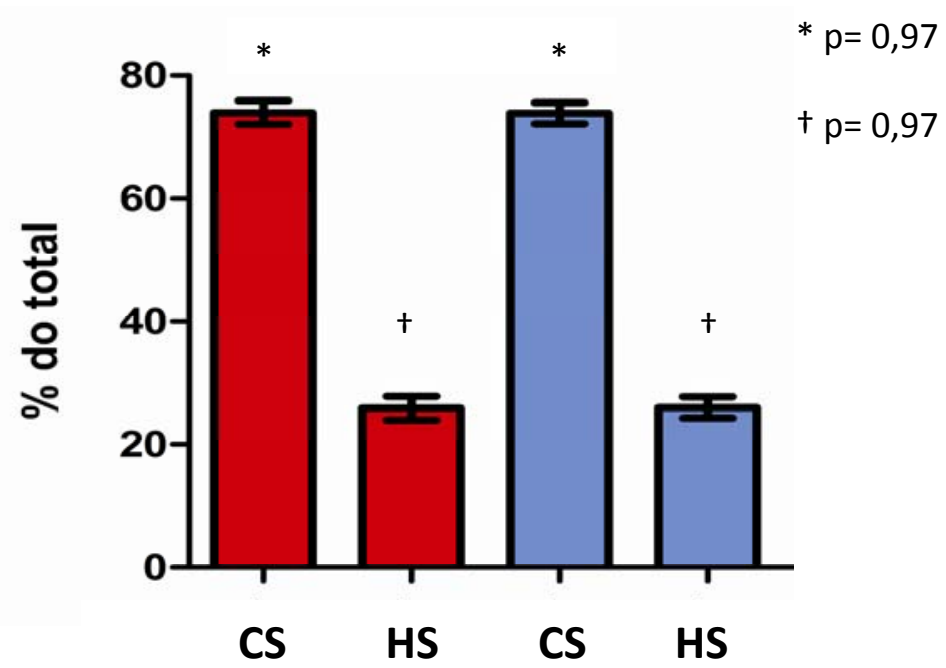

$\mathrm{Cl} \quad$ IUE

Gráfico 2 - Proporção relativa dos diferentes glicosaminoglicanos encontrados na urina de pacientes com cistite intersticial $(\mathrm{Cl})$ e de portadoras de incontinência urinária de esforço (IUE). CS, condroitim sulfato; DS, dermatam sulfato; HS, heparam sulfato. Barras verticais representam os desvios-padrões. Diferença não significativa na comparação de CS urina-IC versus CS urina-IUE e HS urina-IC versus HS urina-IUE $(p=0,97)$.

Quando analisamos outro glicosaminoglicano, o ácido hialurônico, embora a sua concentração média tenha sido menor no grupo de cistite intersticial $(1,71 \pm 2,06 \mathrm{ng} / \mathrm{mg}$ creatinina) quando comparada ao grupo controle $(2,46 \pm 2,07 \mathrm{ng} / \mathrm{mg}$ creatinina) e a ITU (2,36 $\pm 3,09 \mathrm{ng} / \mathrm{mg}$ creatinina), essa diferença não foi significativa $(p=0,45)$. Gráfico 3 . 


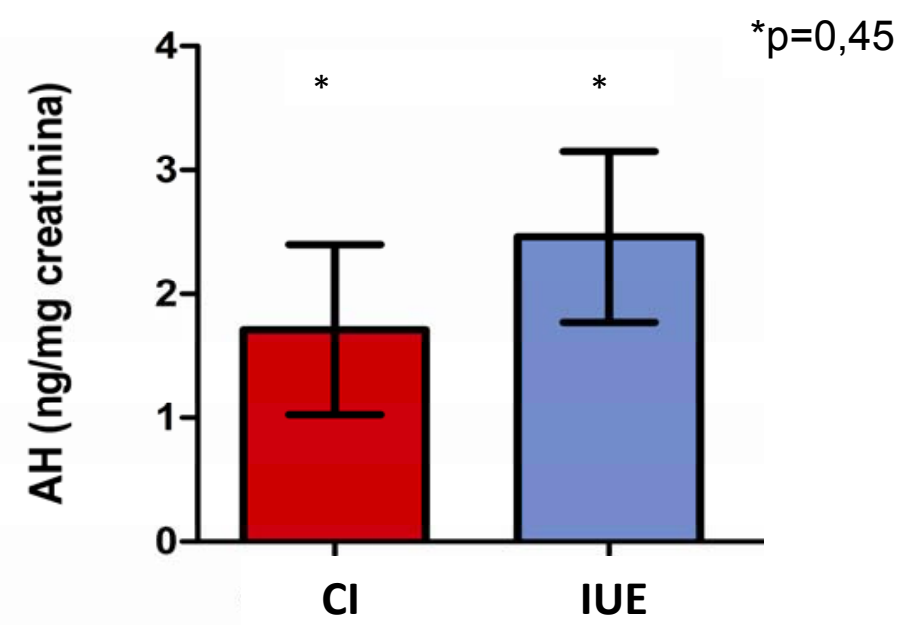

Gráfico 3 - Concentração de ácido hialurônico (AH) urinário de pacientes com cistite intersticial (IC) e portadoras de incontinência urinária de esforço (IUE). Barras verticais representam os erros-padrões. Sem diferença estatisticamente significativa entre os grupos: $p=0,45$.

\section{2 - Glicosaminoglicanos no tecido}

A Figura 5 mostra o perfil eletroforético dos glicosaminoglicanos obtidos dos tecidos de pacientes com cistite intersticial e incontinência urinária de esforço. Nela vemos que o urotélio ambas pacientes apresentam três bandas: uma de menor mobilidade eletroforética (HS), uma intermediária (DS) e uma banda bem tênue acima do DS e que corresponde ao CS. 


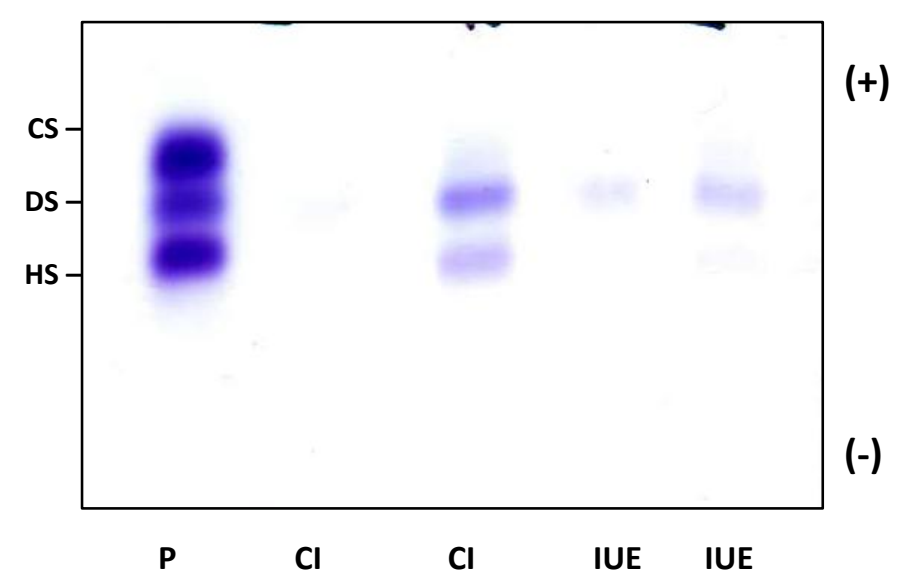

Figura 5 - Perfil eletroforético em 1,3-diaminopropano acetato dos glicosaminoglicanos sulfatados obtidos de urotélio de pacientes com cistite intersticial (IC) e de pacientes controles portadoras de incontinência urinária de esforço (IUE). CS, condroitim sulfato; DS, dermatam sulfato; HS, heparam sulfato; (+), pólo positivo; (-), pólo negativo; P, padrão de Glicosaminoglicanos contendo o equivalente a $5 \mu \mathrm{g}$ em cada banda.

Quando analisamos o conteúdo dos glicosaminoglicanos sulfatados presentes em cada grupo notamos uma grande variabilidade e, embora a média da concentração desses compostos tenha sido maior no grupo de pacientes com cistite intersticial $(3,3 \mu \mathrm{g} / \mathrm{mg}$ tecido seco; variação: $0,58-7,08$ $\mu \mathrm{g} / \mathrm{mg}$ ) do que no grupo da pacientes com incontinência urinária de esforço (2,7 $\mu \mathrm{g} / \mathrm{mg}$ tecido seco; variação: $0,15-5,3 \mu \mathrm{g} / \mathrm{mg}$ ) essa diferença não foi estatisticamente significativa $(p=0,62)$. Gráfico 4 . 


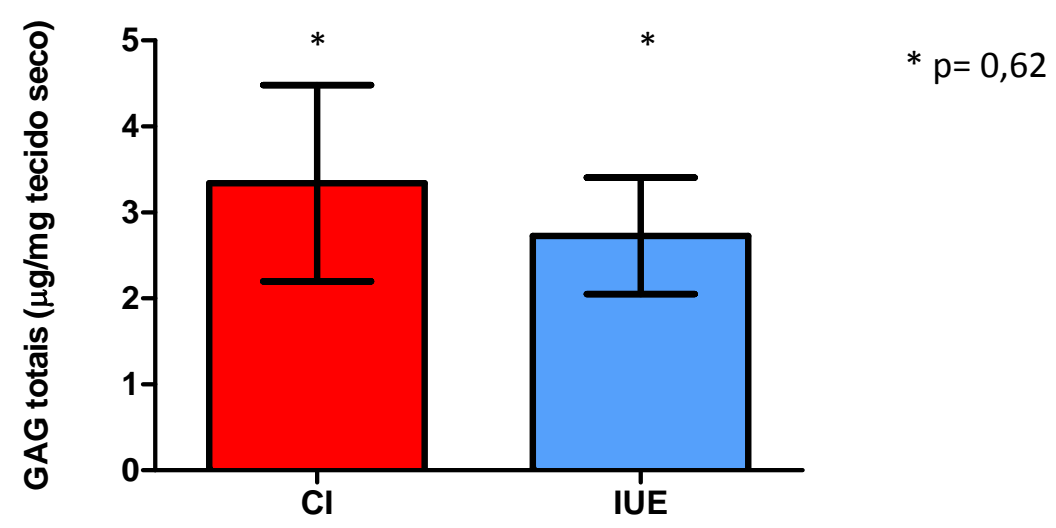

Gráfico 4 - Concentração dos glicosaminoglicanos sulfatados presentes no urotélio de pacientes com cistite intersticial $(\mathrm{Cl})$ e de pacientes portadoras de incontinência urinária de esforço (IUE). Barras verticais representam os desvios-padrões. A diferença entre os grupos não foi significativa (Mann Whitney, $p=0,62$ ).

Também foi feita avaliação da participação relativa dos diferentes glicosaminoglicanos presentes nos tecidos dos dois grupos. Devido à dificuldade em caracterizar o condroitin sulfato por conta da sua pequena concentração, condroitin sulfato e dermatam sulfato (CS + DS) foram analisados em conjunto e comparados com a porcentagem do heparam sulfato(HS) para cada um dos grupos. Gráfico 5. Como evidenciado na figura, o conjunto condroitin sulfato + dermatam sulfato representou o principal componente no urotélio de ambos os grupos não havendo diferença estatisticamente significativa nas proporções desses elementos (média de CS+DS: IC, 74,3\%; CTR, 78\%; média de HS: IC, 25,7\%; CTR, 22\%). 


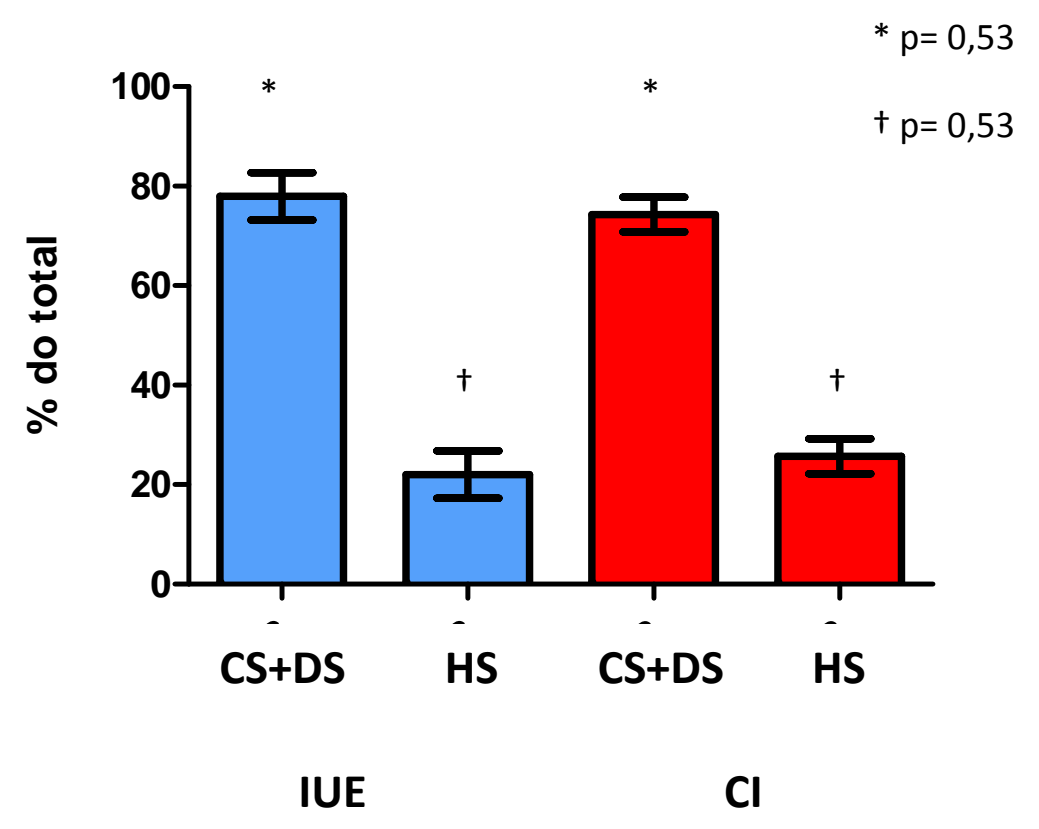

Gráfico 5 - Proporção relativa de cada glicosaminoglicano encontrado em urotélio de pacientes com cistite intersticial $(\mathrm{Cl})$ e de pacientes controles portadoras de incontinência urinária de esforço. CS, condroitim sulfato; DS, dermatam sulfato; HS, heparam sulfato. Barras verticais representam os desvios-padrões. Diferença não significativa na comparação de CTR-CS+DS versus IC-CS+DS $(p=0,53)$ e também na comparação de CTR-HS versus ICHS $(p=0,53)$.

4.3 - Imunofluorescência dos tecidos

O estudo de imunofluorescência foi feito com o intuito de avaliar a expressão, in situ, de proteoglicanos e outros componentes da matriz nas bexigas das portadoras de cistite intersticial. As figuras a seguir são uma amostra representativa das análises de tecidos de 6 pacientes com cistite intersticial e 4 portadoras de incontinência urinária de esforço.

As Figuras 6 (corte correspondente a região mais externa do urotélio) e 7 (corte correspondente a camada mais profunda) mostram um dado 
interessante: nota-se intensa marcação para o ácido hialurônico, tanto na superfície quanto na mucosa, sem um correspondente aumento na expressão do seu receptor, o CD44.

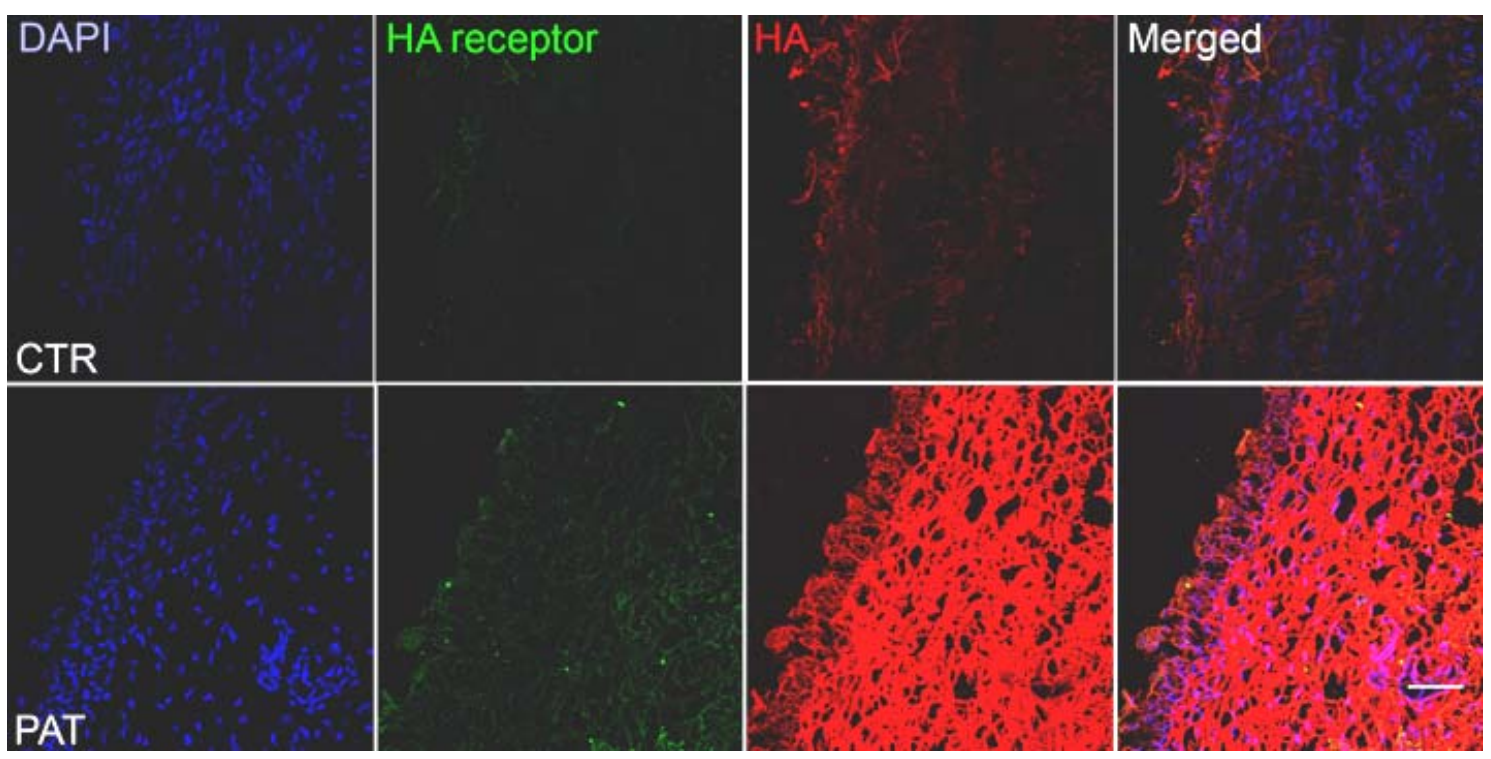

Figura 6- Imunofluorescência de para ácido hialurônico (AH), e seu receptor (CD44) na região mais externa do urotélio vesical. Os tecidos das pacientes portadoras de incontinência urinária de esforço (CTR) e de paciente com cistite intersticial (PAT) foram marcados com anticorpos anti-receptor de ácido hialurônico (verde) e com uma proteína de ligação do ácido hialurônico biotinilada (vermelho). Os núcleos foram corados com DAPI (azul). A sobreposição das marcações aparece no painel à direita (Merged). Barra de escala: $50 \mu \mathrm{m}$. 


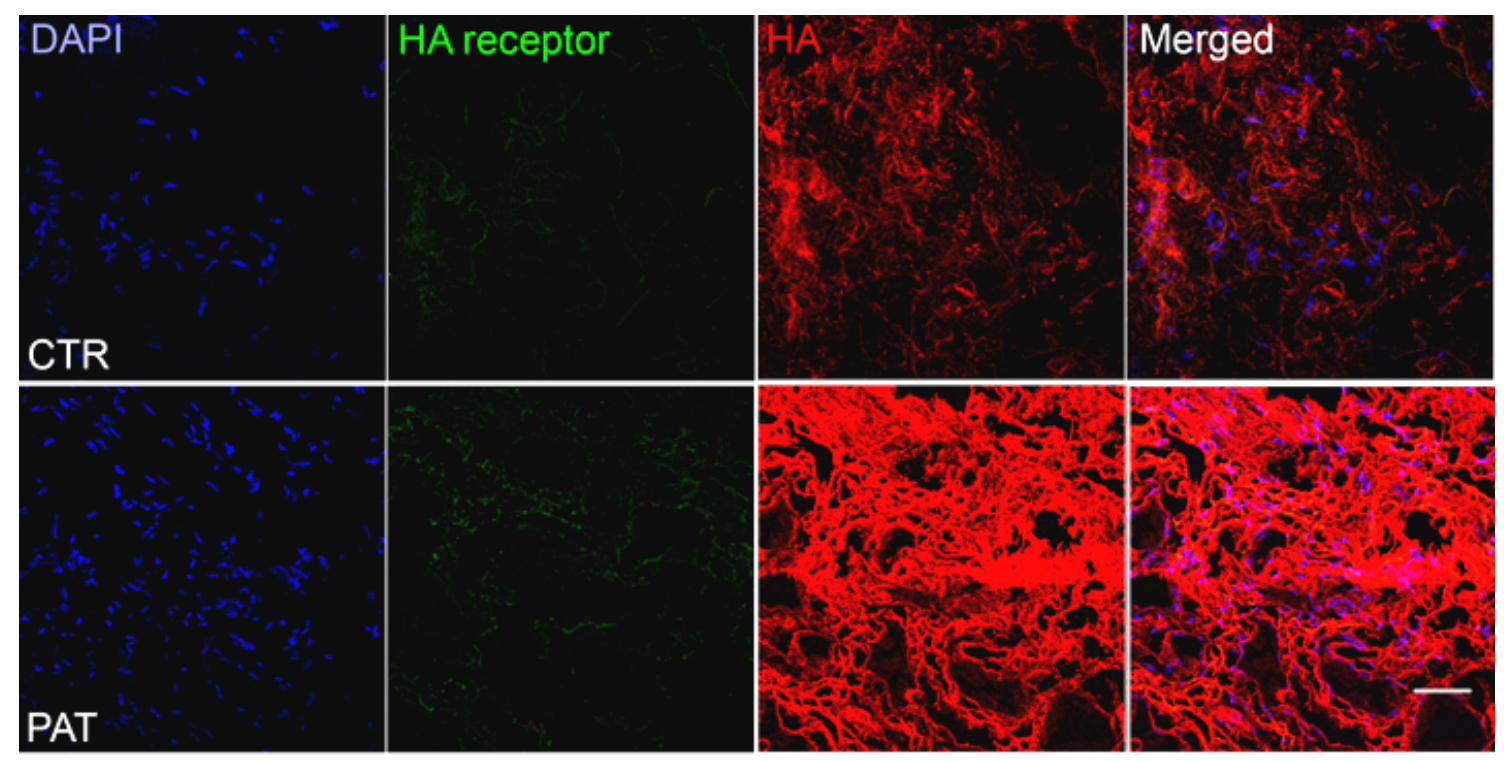

Figura 7- Imunofluorescência para ácido hialurônico (AH), e seu receptor (CD44) na região mais interna do urotélio vesical (mucosa/submucosa). Os tecidos controle (CTR) e de paciente com cistite intersticial (PAT) foram marcados com anticorpos anti-receptor de ácido hialurônico (verde) e com uma proteína de ligação do ácido hialurônico biotinilada (vermelho). Os núcleos foram corados com DAPI (azul). A sobreposição das marcações aparece no painel à direita (Merged). Barra de escala: $50 \mu \mathrm{m}$.

As Figuras 8 (corte correspondente a região mais externa do urotélio + parte da mucosa) e 9 (corte correspondente a camada mais profunda da mucosa/submucosa) mostram a expressão de TGF- $\beta$ e decorim em uma paciente com incontinência urinária de esforço e três tecidos de portadoras de cistite intersticial. Nelas vê-se maior imunomarcação de ambos os componentes em dois das pacientes com cistite intersticial (PAT 1 e 2) se comparado às com incontinência urinária de esforço (CTR), evento esse muito mais acentuado nas camadas mais profundas dos tecidos (Figura 9). 


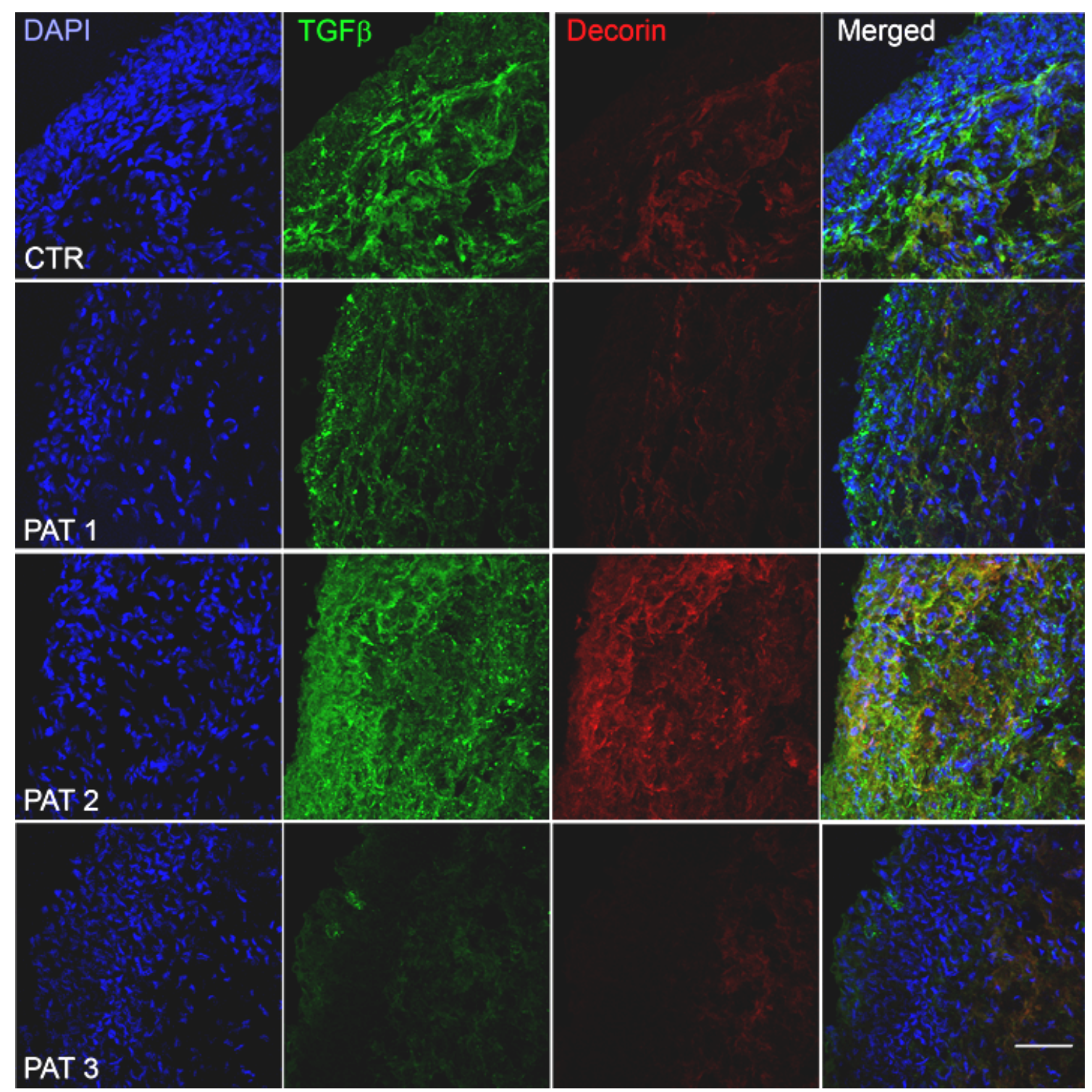

Figura 8- Imunofluorescência de TGF- $\beta$ e de decorim na região mais externa dourotélio vesical. Os tecidos das pacientes com incotinência urinária de esforço (CTR) e de três pacientes com cistite intersticial (PAT 1, PAT 2, PAT 3) foram marcados com anticorpos anti-TGF $\beta$ (verde) e anti-decorim (vermelho). Os núcleos foram corados com DAPI (azul). A sobreposição das marcações aparece no painel à direita (Merged). Barra de escala: $50 \mu \mathrm{m}$. 


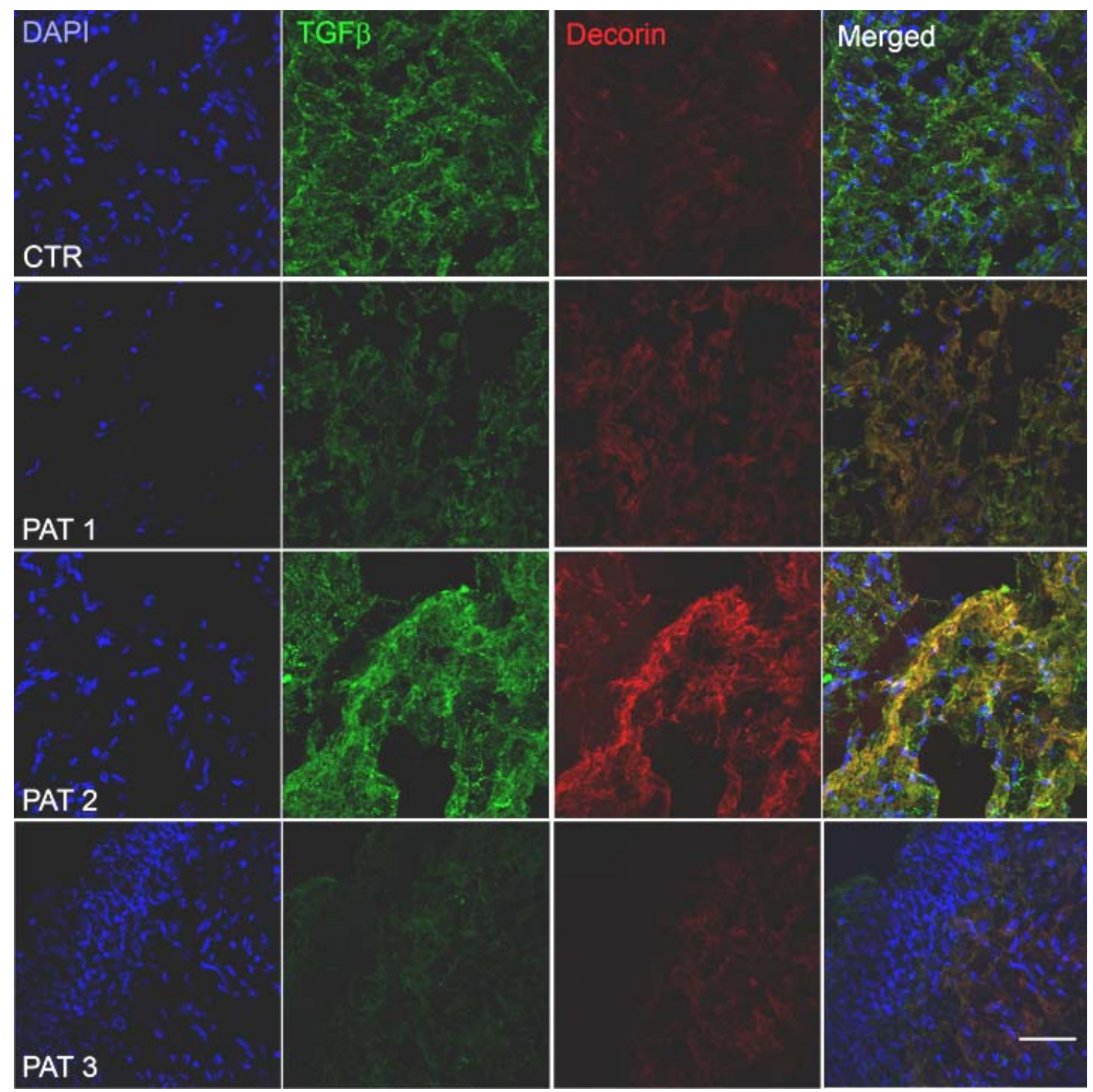

Figura 9- Imunofluorescência de TGF- $\beta$ e de decorim na região mais interna do urotélio vesical (mucosa/submucosa). Os tecidos de uma paciente com incontinência urinária de esforço (CTR) e de três pacientes com cistite intersticial (PAT 1, PAT 2, PAT 3) foram marcados com anticorpos anti-TGF $\beta$ (verde) e anti-decorim (vermelho). Os núcleos foram corados com DAPI (azul). A sobreposição das marcações aparece no painel à direita (Merged). Barra de escala: $50 \mu \mathrm{m}$.

Já as Figuras 10 (corte correspondente a região mais externa do urotélio) e 11 (corte correspondente a camada mais profunda) representam a 
imunomarcação para sindecam-4 e fibronectina. Nessas figuras nota-se intensa marcação para fibronectina em todos as pacientes com cistite intersitical (especialmente em PAT 1 e 3 ) se comparada às com incontinência urinária de esforço (CTR), sendo que essa marcação é mais acentuada nas camadas mais profundas dos tecidos correspondentes. Paralelamente, vê-se uma diminuição importante na expressão do sindecam- 4 dos pacientes tanto na porção mais superficial como nas camadas mais profundas. 


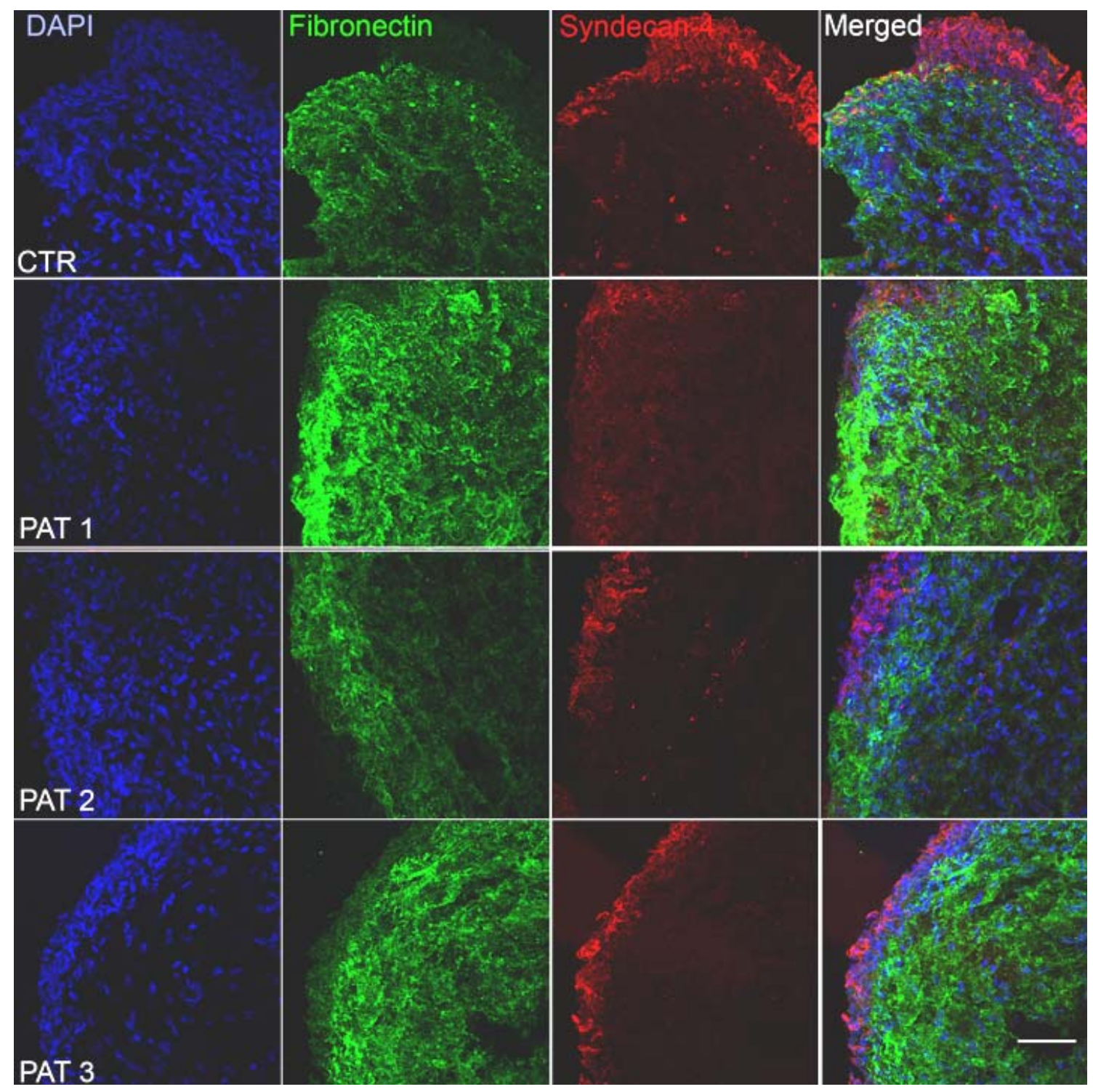

Figura 10- Imunofluorescência de fibronectina e de sindecam-4 na região mais externa do urotélio vesical. Os tecidos de uma paciente com incontinência urinária de esforço (CTR) e de três pacientes com cistite intersticial (PAT 1, PAT 2, PAT 3) foram marcados com anticorpos anti-fibronectina (verde) e antisindecam-4 (vermelho). Os núcleos foram corados com DAPI (azul). A sobreposição das marcações aparece no painel à direita (Merged). Barra de escala: $50 \mu \mathrm{m}$. 


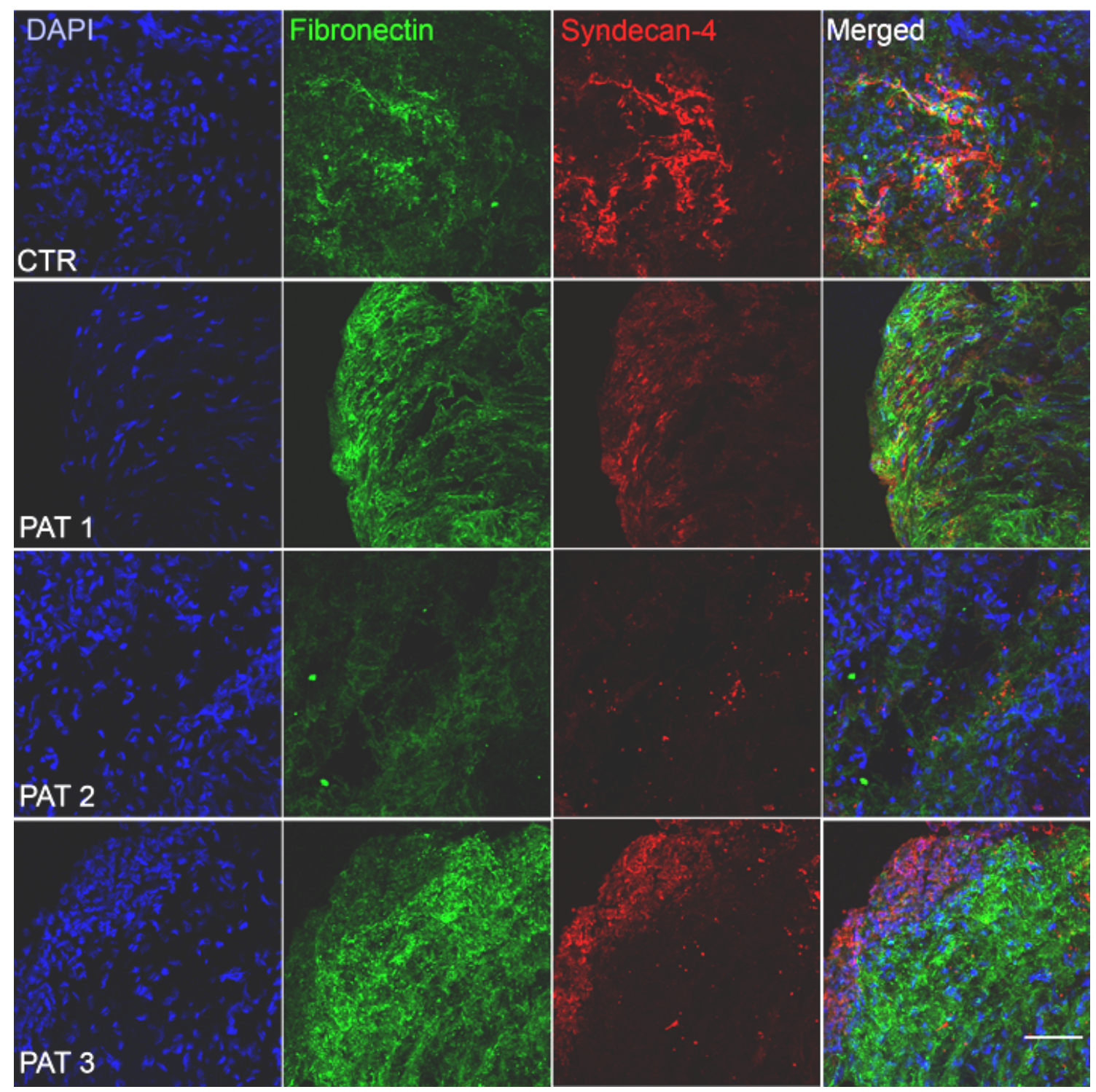

Figura 11- Imunofluorescência de fibronectina e de sindecam-4 na região mais interna do urotélio vesical (mucosa/submucosa). Os tecidos de uma paciente com incontinência urinária de esforço (CTR) e de três pacientes com cistite intersticial (PAT 1, PAT 2, PAT 3) foram marcados com anticorpos antifibronectina (verde) e anti-sindecam-4 (vermelho). Os núcleos foram corados com DAPI (azul). A sobreposição das marcações aparece no painel à direita (Merged). Barra de escala: $50 \mu \mathrm{m}$. 


\section{5- Expressão de RNA total e PCR em tempo real}

Considerando que o ácido hialurônico é um dos principais glicosaminoglicanos produzidos pelo urotélio vesical passamos a analisar o comportamento das enzimas relacionadas à sua biossíntese por PCR em tempo real. Como mostrado nos Gráfico 6, 8 e 9, respectivamente, vê-se claramente que a expressão gênica das sintases 1 e 3 e da hialuronidase tipo I, está diminuída nos urotélios das pacientes com cistite intersticial se comparada a das com incontinência urinária (HAS 1 - $p=0,04$; HAS $-p=0,03$, HYAL 1 - $p$ $=0,03)$. A expressão da sintase 2 do ácido hialurônico não apresentou diferença estatisticamente $(p=0,11)$ significante entre o grupo das portadoras de cistite intersticial e das com incontinência urinária, conforme Gráfico 7. Os valores das sintases e das hialuronidases estão expressos na Tabela 5.

Tabela 5: Expressão relativa dos genes das sintases do ácido hialurônico (HAS 1,2 e 3) e da hialuronidase (HYAL 1) em pacientes com cistite intersticial (Cl) e incontinência urinária de esforço (IUE).

\begin{tabular}{|c|c|c|c|c|}
\hline $\begin{array}{c}\text { Expressão } \\
\text { relativa do } \\
\text { mRNA }\end{array}$ & HAS 1 & HAS 2 & HAS 3 & HYAL 1 \\
\hline $\mathrm{Cl}$ & $\begin{array}{c}4,671 \mathrm{e}-006 \pm \\
1,022 \mathrm{e}-006 \\
N=6\end{array}$ & $\begin{array}{c}4,671 \mathrm{e}-006 \pm \\
1,022 \mathrm{e}-006 \\
N=6\end{array}$ & $\begin{array}{c}0,0001689 \pm \\
7,199 e-005 \\
N=6\end{array}$ & $\begin{array}{c}0,001236 \pm \\
0,0002711 \\
N=6\end{array}$ \\
\hline IUE & $\begin{array}{c}2,200 e-005 \pm \\
7,873 e-006 \\
N=5\end{array}$ & $\begin{array}{c}2,200 \mathrm{e}-005 \pm \\
7,873 \mathrm{e}-006 \\
N=5\end{array}$ & $\begin{array}{c}0,0005039 \pm \\
0,0001327 \\
N=5\end{array}$ & $\begin{array}{c}0,01583 \pm \\
0,006116 \\
N=5\end{array}$ \\
\hline$p$ & 0,03 & 0,17 & 0,04 & 0,02 \\
\hline
\end{tabular}




\section{Ácido Hialurônico Sintase 1}

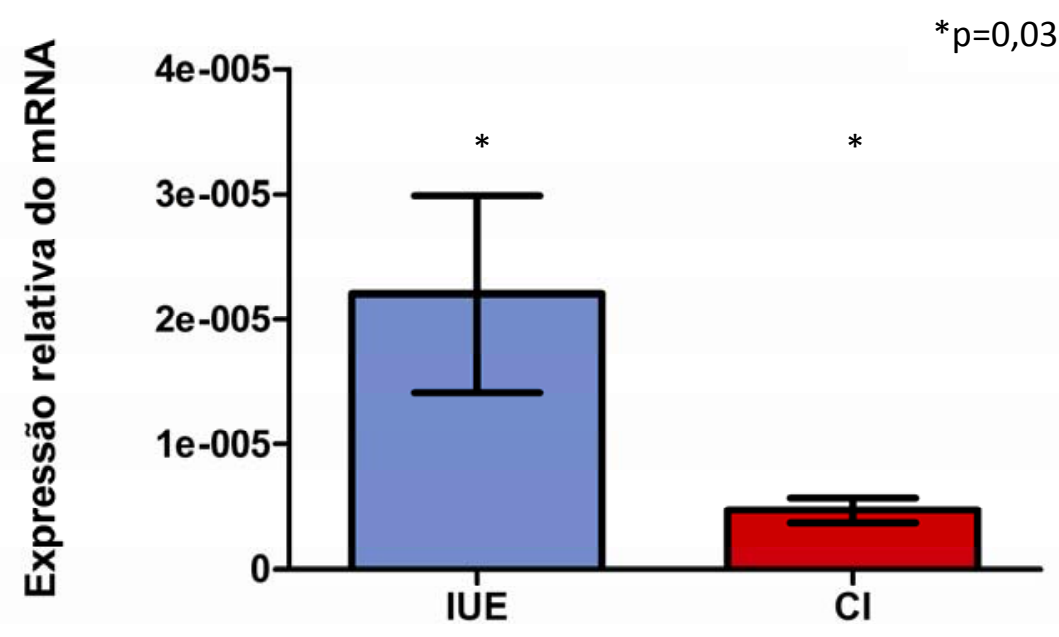

Gráfico 6 - PCR em tempo real dos genes das sintases do ácido hialurônico: HAS 1. Barras verticais representam os desvios-padrões de três reações para cada gene. Existe diferença significativamente estatística entre os grupos: $p=0,04$.

\section{Ácido Hialurônico Sintase 2}

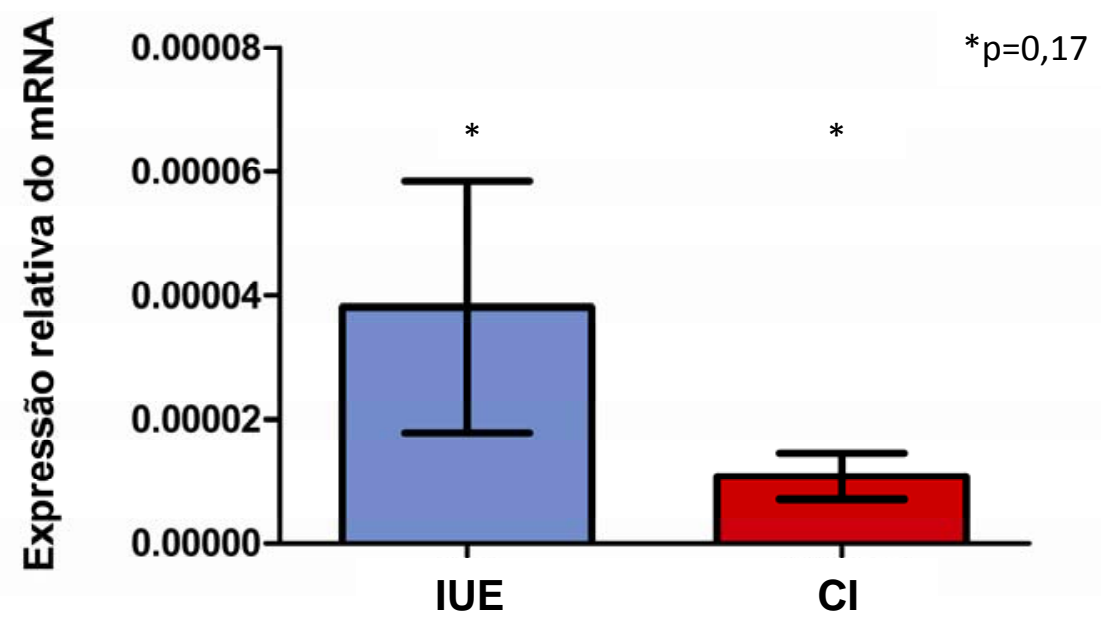

Gráfico 7 - PCR em tempo real dos genes das sintases do ácido hialurônico:HAS 2. Barras verticais representam os desvios-padrões de três 
reações para cada gene. Não existe diferença significativamente estatística entre os grupos: $p=0,11$.

\section{Ácido Hialurônico Sintase 3}

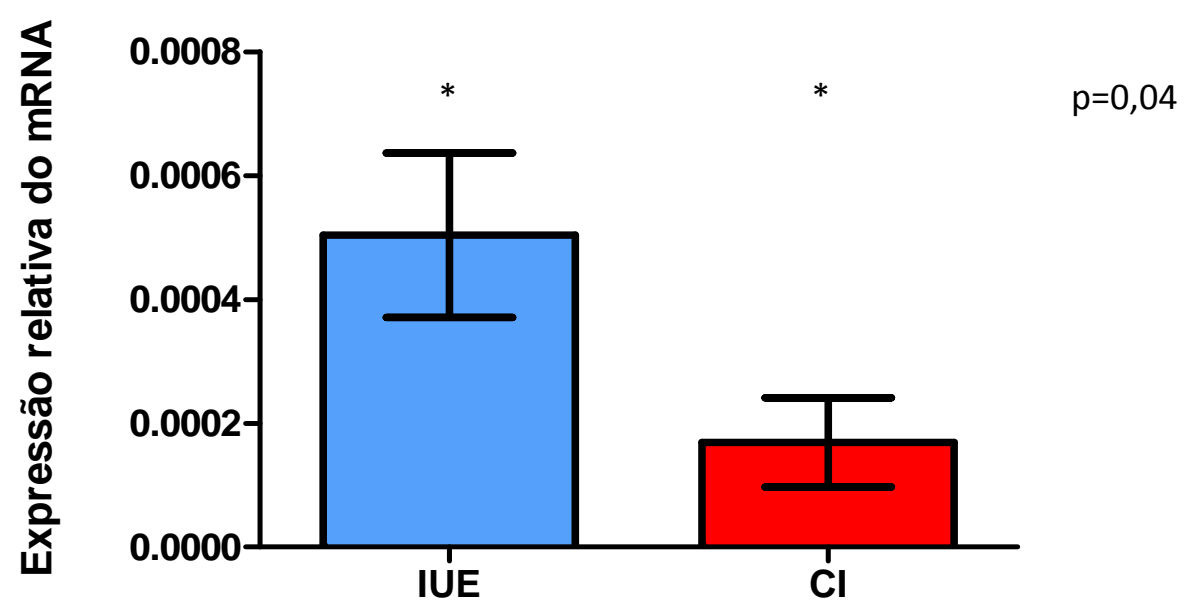

Gráfico 8- PCR em tempo real dos genes das sintases do ácido hialurônico: HAS 3. Barras verticais representam os desvios-padrões de três reações para cada gene. Existe diferença significativamente estatística entre os grupos: $\mathrm{p}=0,03$.

\section{Hialuronidase}

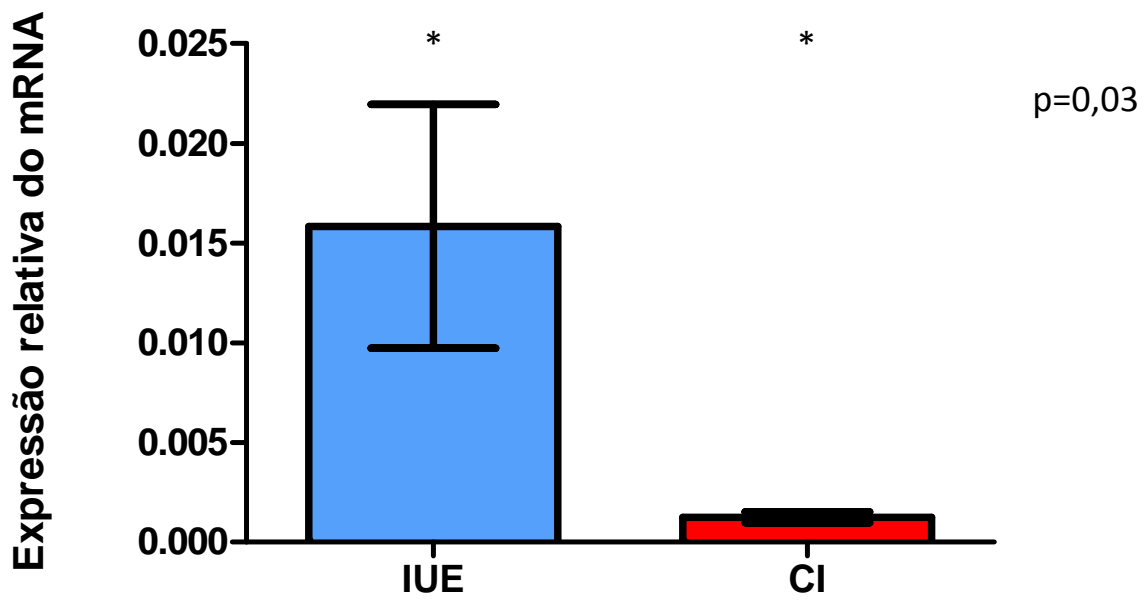

Gráfico 9- PCR em tempo real da enzima de degradação do ácido hialurônico - hialuronidase I (Hyal I). Barras verticais representam os desvios-padrões de 
três reações para cada gene. Existe diferença significativamente estatística entre os grupos: $p=0,03$. 


\section{Discussão}

O diagnóstico da cistite intersticial continua desafiador. Os pacientes se apresentam com um amplo espectro de sintomas, resultando em grande dificuldade de diagnóstico (Hanno, Burks et al. 2011). Há inclusive variação dos sintomas conforme a idade da paciente, com diagnósticos cada vez em pacientes mais jovens (Rais-Bahrami, Friedlander et al. 2012). Essa controvérsia do diagnóstico pode ser reflexo do desentendimento dos mecanismos da doença. Das vários teorias disponíveis, as alterações dos glicosaminoglicanos da mucosa vesical mereceram atenção porque foi proposto que sua ação envolveria uma "proteção" da mucosa contra agentes agressores. Apesar de o processo etiopatogênico da cistite intersticial ser ainda desconhecido, admite-se que haja perda da camada de glicosaminoglicanos que reveste o urotélio, tornando-o mais susceptível à passagem de componentes presentes na urina, contribuindo para a inflamação local (Lilly and Parsons 1990, Parsons 2007). A concentração urinária dos glicosaminoglicanos tem sido descrita como inalterada, diminuída e ainda aumentada nas pacientes com cistite intesticial (Wei, Politano et al. 2000). Por outro lado, ainda não há consenso quanto à concentração de seus níveis teciduais. Também aqui há grande variação na literatura, dificultando assim o estabelecimento de um padrão de expressão dos glicosaminoglicanos nas pacientes portadoras de cistite interstical (Nickel, Emerson et al. 1993, Hanno, Landis et al. 1999, Hanno and Sant 2001, Soler, Bruschini et al. 2006, Soler, Bruschini et al. 2008). É possível ainda que diferentes momentos, envolvendo maior ou menor grau de atividade da doença, possam apresentar perfis distintos de suas proteínas. Nosso estudo foi feito com intuito de tentar compreender a expressão dos glicosaminoglicanos nestas pacientes neste cenário de grandes indagações. Além da identificação e caracterização dos glicosaminoglicanos sulfatados e ácido hialurônico na urina e tecido, procuramos ampliar nossa avaliação estudando parte de sua expressão genética. Conseguimos avaliar a expressão das sintases e da enzima de degradação do ácido hialurônico.

Nos estudos originais foi demonstrado que pacientes com cistite intersticial excretam na urina menor concentração de glicosaminoglicanos que 
pacientes controles. Porém, outros trabalhos foram feitos e os resultados são contraditórios (Erickson, Ordille et al. 1997, Erickson, Xie et al. 2002) havendo, inclusive, quem descreva excreção de glicosaminoglicanos urinários aumentada em pacientes com cistite intersticial mais grave (Akcay and Konukoglu 1999, Lokeshwar, Selzer et al. 2005, Lokeshwar, Selzer et al. 2006). Embora os métodos sejam diferentes nos diversos estudos mencionados, nossos resultados são condizentes com os trabalhos de Parsons e Hurst (Parsons and Hurst 1990) que também mostraram uma significativa diminuição da excreção urinária dos glicosaminoglicanos sulfatados das pacientes com cistite intersticial se comparada à encontrada nos controles. Além disso, diferentemente dos estudos anteriores, a técnica empregada nesse estudo pode demonstrar que essa redução na excreção urinária de glicosaminoglicanos de pacientes com cistite intersticial ocorreu de forma uniforme, não havendo predileção por um ou outro glicosaminoglicanos da urina. Quanto ao ácido hialurônico, embora a média de sua concentração urinária tenha sido menor no grupo com cistite intersticial não houve diferença significativa quando comparado ao controle ou as portadoras de infecção urinária aguda.

Porém, níveis urinários de glicosaminoglicanos não necessariamente refletem seu status urotelial (Soler, Bruschini et al. 2008). O perfil dos glicosaminoglicanos nas bexigas dos pacientes com cistite intersticial ainda é controverso, visto que alguns autores não encontraram mudança em seu conteúdo (Nickel, Emerson et al. 1993, Parsons 2011). No presente estudo não encontramos diferença estatisticamente significativa na concentração dos glicosaminoglicanos sulfatados do urotélio das pacientes com cistite intersticial se comparada a dos controles. Além disso, os diferentes tipos de glicosaminoglicanos (condroitin sulfato + dermatam sulfato $x$ heparam sulfato) que compõem o urotélio também não foram diferentes entre os grupos. Ainda, contrastando com os dados previamente descritos por Hurst e Zebrowski (Hurst 1994), que encontraram o heparam sulfato como sendo o glicosaminoglicano predominante nos urotélios de pacientes com cistite intersticial (55\% do total de glicosaminoglicanos), neste estudo, o principal encontrado nos urotélios dascistites intersticiais foi uma combinação de condroitin sulfato e dermatam 
sulfato, que correspondiam a cerca de $80 \%$ do total, e essa proporção foi igual a da encontrada nos controles. Métodos diferentes de extração e análises dos diferentes glicosaminoglicanos poderiam justificar tais diferenças. Além disso, o pequeno tamanho dos fragmentos pode ter prejudicado as análises e dificultado a interpretação desses dados.

Os glicosaminoglicanos foram também analisados por imunofluorescência direta. O TGF- $\beta$, um fator de crescimento diretamente envolvido em fenômenos inflamatórios e o decorim, um proteoglicano formado por cadeias de condroitin sulfato e dermatam sulfato e envolvido na regulação de várias funções celulares como proliferação, adesão e migração e que, em certas circunstâncias intermedeia a ligação do TGF- $\beta$ com seu receptor de membrana (Shi and Massague 2003), mostraram aumento combinado de suas expressões, pelo menos em parte dos urotélios de cistite intersticial. De fato, fatores de crescimento já foram descritos como aumentados nestes pacientes (Schwalenberg, Stolzenburg et al. 2011). Além disso, notamos uma intensa marcação de fibronectina nos tecidos de cistite intersticial, especialmente nas camadas mais profundas do tecido, aliada a diminuição da marcação de sindecam-4, indicando descamação celular e aumento do remodelamento da matriz extracelular. Esses achados estão de acordo com estudo prévio do realizado pelo nosso grupo, no qual foi verificado, em modelos animais de cistite intersticial, perda da expressão de heparam sulfato e sindecam na superfície do urotélio de ratos após indução de inflamação com sulfato de protamina (Soler, Bruschini et al. 2008). Embora não tenhamos encontrado um padrão homogêneo de imunofluorescência para todos os pacientes com cistite intersticial, nossos achados estão de acordo com o de outros pesquisadores que, analisando biomarcadores por imuno-histoquímica no urotélio de pacientes com cistite verificaram padrões distintos de marcação, ora com predomínio de um ora de um conjunto de componentes da matriz, porém todos os perfis diferentes dos encontrados nos urotélios normais (Hurst, Roy et al. 1996, Hauser, Dozmorov et al. 2008).

Outro passo importante no presente trabalho foi verificar a expressão de ácido hialurônico e seu receptor CD44 nos tecidos. O ácido hialurônico é um componente-chave da matriz extracelular devido às suas propriedades 
viscoelásticas e sua capacidade higroscópica, provendo hidratação e turgidez celular. O ácido hialurônico forma uma base com a qual outros proteoglicanos podem se ligar e tem 3 funções básicas (Nusgens 2010): interage de forma autócrina com receptores celulares do próprio ácido hialurônico; tem ação parácrina com vários componentes da matriz extracelular nas células vizinhas; e aqueles recém sintetizados interagem com receptores da superfície celular, como o cluster determinante CD 44. (Girish and Kemparaju 2007). Alterações no ácido hialurônico podem levar a mudanças na matriz extracelular (Itano and Kimata 2002). Em nosso estudo o ácido hialurônico mostrou intensa marcação no urotélio de cistite intersticial se comparado ao controle com incontinência urinária de esforço, ao passo que a marcação do CD44 não mostrou marcação significativamente diferente nos dois tecidos, o que poderia representar, num primeiro momento, um paradoxo. O CD44 é o principal receptor de membrana para o ácido hialurônico e é responsável, entre outras coisas, pela sua ligação e internalizarão para o interior das células onde esse elemento é degradado por hialuronidases lisossomais e os produtos dessa digestão reaproveitados para nova síntese (Knudson, Chow et al. 2002). A combinação de intensa marcação de ácido hialurônico sem um correspondente aumento da marcação do seu receptor poderia indicar uma mudança do seu turnover no urotélio de cistite intersticial fazendo com que esse composto seja "armazenado" no interstício e, possivelmente contribua, por meio da interação com outros componentes da matriz, para o remodelamento e recuperação do urotélio comprometido pela inflamação.

São poucos os estudos feitos com o intuito de avaliar a expressão de genes envolvidos na biossíntese dos glicosaminoglicanos, havendo uma descrição recente de que a expressão de uma das enzimas de síntese do ácido hialurônico (HAS 1) está aumentada em biópsias e em cultura de células de pacientes com cistite intersticial (Lokeshwar, Selzer et al. 2006). As sintases do ácido hialurônico ocorrem em 3 isoformas (HAS 1, HAS 2 e HAS 3) que produzem ácido hialurônico com diferentes tamanhos e funções. Apesar da seqüência de aminoácidos destas isoenzimas ser 50 a $70 \%$ idênticas, as sequências genéticas estão localizadas em cromossomos distintos: hCh19HAS1, hCh8-HAS2 e hCh16-HAS3 (Girish and Kemparaju 2007). No presente 
trabalho mostramos, de forma inédita, que a expressão gênica das sintases $1 \mathrm{e}$ 3 do ácido hialurônico e também de uma das enzimas de degradação desse composto, a hialuronidase I (HYAL I) está surpreendentemente diminuída na maioria dos urotélios provenientes de pacientes com cistite intersticial quando comparado aos controles com incontinência urinária de esforço, tendo em vista a maior imunomarcação do ácido hialurônico naquelas pacientes. Possivelmente em função da menor amostragem, a sintase 2 do ácido hialurônico (HAS 2) não alcançou diferença estatística.

Considerando que o comprometimento inflamatório do urotélio não ocorra de forma uniforme, nossos resultados e também os de Hauser e cols. (Hauser, Dozmorov et al. 2008) sugerem perfis distintos de envolvimento e expressão de diversos componentes inflamatórios e da matriz extracelular das pacientes com cistite intersticial. Essas mudanças parecem ocorrer na dependência dos diferentes estágios de inflamação e/ou remodelamento a que cada segmento do urotélio disfuncional da bexiga esteja sujeito, de forma que talvez seja improvável que um eventual padrão de expressão dos glicosaminoglicanos para pacientes com cistite intersticial seja encontrado. Sabe-se, de forma geral, que estes urotélios apresentam padrões distintos de marcação dos componentes da matriz, porém todos os perfis diferentes dos encontrados nos urotélios normais (Hurst, Roy et al. 1996, Hauser, Dozmorov et al. 2008).

Por causa desta variação, o estudo somente dos glicosaminoglicanos em urina e tecidos pode ser insuficiente para compreender a fisiopatologia da doença. Até mesmo as alterações histológicas, patognomônicas em outras épocas, não são hoje consideradas específicas da cistite intersticial (Hanno, Lin et al. 2010). A avaliação da cistite intersticial baseada predominantemente na expressão de glicoproteínas, cujo metabolismo está em constante transformação, parece assim parca. Nesse sentido, a caracterização da expressão dos genes do ácido hialurônico e de outros glicosaminoglicanos pode ter papel fundamental no entendimento desta doença. A participação da genética na cistite intersticial já foi sugerida quando se encontrou maior correlação da doença em gêmeos (Tunitsky, Barber et al. 2012), em parentes 
de primeiro grau (Warren, Jackson et al. 2004) e em portadores de polimorfismos de receptores adrenérgicos (Dimitrakov and Guthrie 2009).

A limitação deste estudo concentra-se principalmente no pequeno número de pacientes envolvidos nas amostras. A inclusão de pacientes com incontinência urinária de esforço parece não encontrar problemas para sua ampliação. No entanto, para fins de pesquisa científica pacientes com cistite intersticial devem obedecer a critérios específicos para serem incluídas nos estudos (Hanno and Sant 2001). Se por um lado normatizam a amostra das pesquisas, por outro fazem com que até $60 \%$ das pacientes com cistite intersticial não consigam preencher seus critérios diagnósticos (Hanno, Landis et al. 1999). Essa limitação impõe ao centro do estudo um maior número de pacientes com diagnóstico clínico de cistite intersticial para serem selecionadas à inclusão dos critérios de pesquisa. Ao mesmo tempo, por se tratar de um centro terciário, pode ter havido maior representação de casos mais graves da doença, que não puderam ser assistidos nos centros primário e secundários de atenção à saúde. Outro fator limitante é a necessidade de amostras teciduais de seres humanos. As biópsias vesicais são pouco mórbidas se feitas com critério. Mas, invariavelmente recolhem pequena quantidade de tecido $(0,5 \times 0,5 \mathrm{~cm}$ de tecido em média nesse estudo), que representa por sua vez uma pequena porção da bexiga. Esse material teve que ser usado para o estudo histopatológico, de imunofluorescência e de expressão gênica. Questões éticas envolvendo pesquisas em seres humanos são bem estabelecidas e nos impedem de re-coletar mais material sem seguir rígidos princípios. Vale mencionar ainda que os estudos da literatura apresentam metodologias variáveis, como por exemplo, para extração dos glicosaminoglicanos. Dessa forma, a restrição de pacientes e a limitação das amostras teciduais consistiram os maiores desafios metodológicos.

Tentar unir todos os achados desse estudo num único raciocínio parece ousado. Mas, imaginando que todos os fenômenos listados acima estejam ligados, pode-se supor que um processo extremamente complexo e paradoxal de intensa atividade inflamatória esteja ocorrendo nas pacientes com cistite intersticial. Por um lado, existiria um aumento de fatores de crescimento, aqui demonstrado pelo aumento do TGF- $\beta$. De forma complementar encontramos 
aumento de decorim, que por sua vez interage com o próprio TGF- $\beta$. Lembrando que o decorim é um proteoglicano de condroitin e dermatan sulfato, faz sentido que o encontremos aumentado, porque ele é justamente o glicosaminoglicano predominente no urotélio destas pacientes. Também encontramos maior expressão de fibronectina, compondo uma possível tentativa de remodelamento do tecido. A reação urotelial seria marcada por um acúmulo de ácido hialurônico, também sugerindo remodelamento tecidual. Por outro lado e em contraste a esses aumentos, estaria a atividade enzimática globalmente reduzida. A diminuição da atividade da enzima de degradação do ácido hialurônico, a hialuronidase, poderia contribuir para o acúmulo “intencional” do ácido hialurônico. É possível ainda que a maior concentração do ácido hialurônico exerça uma espécie de inibição de sua síntese, levando a menor atividade de suas sintases. Esse cenário parece o contrário da intensa atividade dessas enzimas que ocorre em neoplasias (Kramer, Escudero et al. 2011). 


\section{Conclusão}

O estudo dos glicosaminoglicanos permitiu concluir que:

1- Pacientes com cistite intersticial tem menor concentração de glicosaminoglicanos sulfatados na urina que pacientes com incontinência urinária de esforço, mantendo a mesma proporção de condroitin sulfato, heparan sulfato e dermatan sulfato;

2- A concentração de ácido hialurônico na urina foi a mesma nas portadoras de cistite intersticial e de incontinência urinária de esforço;

3 - Pacientes com cistite intersticial apresentaram menor expressão tecidual de sindecan que as portadoras de incontinência urinária de esforço;

4 - Pacientes com cistite intersticial apresentaram maior expressão tecidual de fibronectina, decorin e TGF- $\beta$ que as portadoras de incontinência urinária de esforço;

5 - Pacientes com cistite intersticial apresentaram maior expressão tecidual de ácido hialurônico que as portadoras de incontinência urinária de esforço;

6- A expressão tecidual das sintases 1 e 3 do ácido hialurônico e da hialuronidase foram menor nas portadoras de cistite intersticial do que nas portadoras de incontinência urinária de esforço. 


\section{Anexos}

\section{1 - Anexo 1: Critérios para o diagnóstico de Cistite Intersticial estabelecidos pelo National Institutes of Arthritis, Diabetes, Digestive and Kidney Diseases:}

Critérios necessários: Glomerulações ou úlcera de Hunner à cistoscopia e dor referida à bexiga ou urgência urinária. As glomerulações devem ocorrer após distensão vesical, sob anestesia, sob pressão de 80 a $100 \mathrm{~cm} \mathrm{H}_{2} \mathrm{O}$, por 1 a 2 minutos. A bexiga deve ser distendida por até duas vezes antes da avaliação. As glomerulações devem ser difusas (presentes em pelo menos 3 quadrantes da bexiga) e deve haver no mínimo 10 glomerulações por quadrante. Estas não devem encontrar-se no trajeto do cistoscópio, já que o contato do aparelho pode produzir artefatos.

A presença de qualquer dos critérios abaixo exclui o diagnóstico de Cistite Intersticial:

1. Capacidade vesical maior que $350 \mathrm{cc}$ à cistometria com gás ou líquido, com o paciente acordado.

2. Ausência de desejo miccional intenso com enchimento vesical de 1200 cc de gás ou 150 cc de líquido durante a cistometria, com velocidade de enchimento de 30 a 100 cc por minuto.

3. Contrações involuntárias fásicas durante a cistometria com à velocidade de enchimento citada.

4. Duração de sintomas menor que 9 meses.

5. Ausência de noctúria.

6. Alívio dos sintomas com o uso de antimicrobianos, antissépticos urinários, anticolinérgicos ou antiespasmódicos.

7. Frequência urinária, enquanto acordado, menor que 8 vezes ao dia.

8. Diagnóstico de cistite bacteriana ou prostatite nos últimos 3 meses.

9. Litíase vesical ou ureteral.

10. Herpes genital ativa.

11. Câncer uterino, cervical, vaginal ou uretral.

12. Divertículo uretral.

13. Cistite por ciclofosfamida ou outro agente químico.

14. Cistite tuberculosa.

15. Cistite por radiação.

16. Tumores malignos ou benignos vesicais.

17. Vaginite

18. Idade menor que 18 anos.

7.2 - Anexo 2: Questionário de Sintomas e Incômodo (O’Leary) e Puff Scale 


\section{QUESTIONÁRIO DE SINTOMAS}

Q 1. Durante o último mês, com que freqüênciavocê sentiu

necessidade forte para urinar com pouco ou nenhum aviso prévio?

0 .- nenhuma vez

1.- menos que 1 em 5

2 .- menos que metade das vezes

3. - por volta de metade das vezes

4 .- mais que metade das vezes

5 .- quase sempre

02. Durante o último mês, você teve que urinar com menos

de $\mathbf{2}$ horas depois de você terminar de urinar?

0 .- nenhuma vez

1.- menos que 1 em 5

2 .- menos que metade das vezes

3. - por volta de metade das vezes

4 .- mais que metade das vezes

5 .- quase sempre

Q3. Durante o último mês, com que freqüência você acordou à noite para urinar?

0. - nenhuma vez

1 .- uma vez por noite 
2. - 2 vezes por noite

$3 .-3$ vezes por noite

4. - 4 vezes por noite

5 .- 5 ou mais vezes

04. Durante o último mês, você sentiu dor

ou queimação em sua bexiga?

0 .- nenhuma vez

2. - algumas vezes

3. - quase sempre

4. - muito freqüentemente

5. - sempre

\section{QUESTIONÁRIO DE INCÔMODO}

Durante o último mês, quantode cada um dos itens abaixo tem sido um incômodo para você?

\section{Q1. Urinar freqüentemente durante o dia?}

0 .- nenhum incômodo

1. - incômodo muito pequeno

2 .- incômodo pequeno

3 .- incômodo moderado

4. - grande incômodo

Q2. Acordar durante à noite para urinar?

0 .- nenhum incômodo

1. - incômodo muito pequeno 
2 .- incômodo pequeno

3 .- incômodo moderado

4. - grande incômodo

\section{Q3. Precisar urinar com urgência?}

0 .- nenhum incômodo

1. - incômodo muito pequeno

2 .- incômodo pequeno

3 .- incômodo moderado

4. - grande incômodo

Q4. Queimação, dor, desconforto ou pressão em sua

bexiga?

0 .- nenhum incômodo

1. - incômodo muito pequeno

2 .- incômodo pequeno

3 .- incômodo moderado

4. - grande incômodo 


\section{Questionário de Sintomas: Puff Scale}

\section{Escala de Sintomas de Dor Pélvica e Urgência / Freqüência}

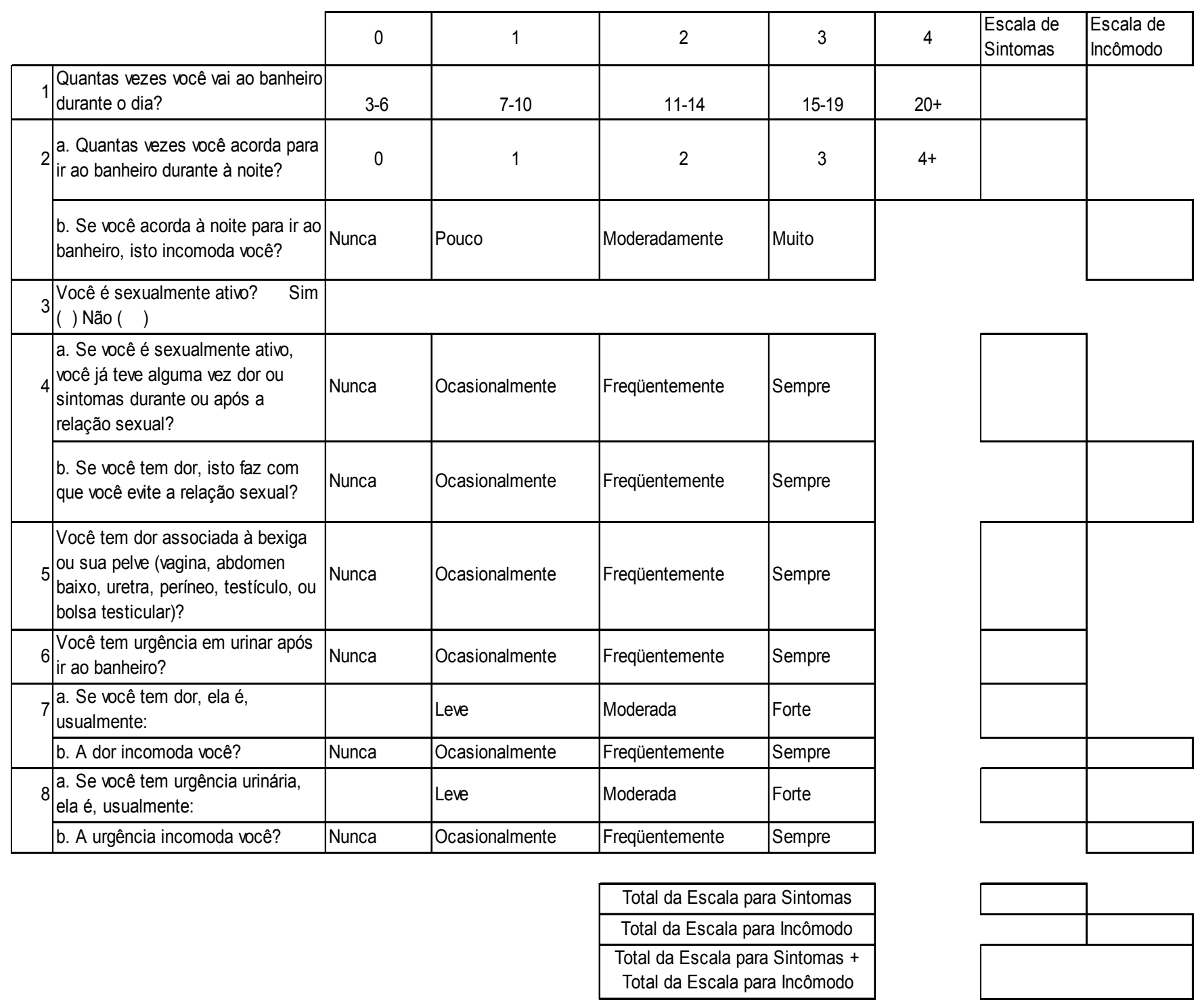


7.3- Anexo3:(Hohenfellner, Nunes et al. 1992) Fomento

Esse estudo foi financiado pela Fundação de Amparo à Pesquisa do Estado de São Paulo - FAPESP, sob número 08/56788-7. O relatório final e a prestação de contas foram integralmente aprovados. 


\section{Referências}

Abrams, P., et al. (2002). "The standardisation of terminology of lower urinary tract function: report from the Standardisation Sub-committee of the International Continence Society." Am J Obstet Gynecol 187(1): 116-126.

Akcay, T. and D. Konukoglu (1999). "Glycosaminoglycans excretion in interstitial cystitis." Int Urol Nephrol 31(4): 431-435.

Avraham, S., et al. (1989). "Molecular cloning of a cDNA that encodes the peptide core of a mouse mast cell secretory granule proteoglycan and comparison with the analogous rat and human cDNA." Proc Natl Acad Sci U S A 86(10): 3763-3767.

Berto, A. G., et al. (2001). "Galactosaminoglycans from normal myometrium and leiomyoma." Braz J Med Biol Res 34(5): 633-637.

Brimacombe, J. S. and M. Stacey (1964). "Mucopolysaccharides in Disease." Adv Clin Chem 15: 199-234.

Clemens, J. Q., et al. (2005). "Prevalence and incidence of interstitial cystitis in a managed care population." J Urol 173(1): 98-102; discussion 102.

Curhan, G. C., et al. (1999). "Epidemiology of interstitial cystitis: a population based study." J Urol 161(2): 549-552.

Dahl, L., et al. (1983). "The concentration of hyaluronate in amniotic fluid." Biochem Med 30(3): 280-283.

De Klerk, D. P., et al. (1984). "Glycosaminoglycans of human prostatic cancer." J Urol 131(5): 1008-1012.

Dietrich, C. P. (1984). "A model for cell-cell recognition and control of cell growth mediated by sulfated glycosaminoglycans." Braz J Med Biol Res 17(1): 5-15.

Dietrich, C. P. and S. M. Dietrich (1976). "Electrophoretic behaviour of acidic mucopolysaccharides in diamine buffers." Anal Biochem 70(2): 645-647. 
Dietrich, C. P., et al. (1993). "Anomalous structure of urinary chondroitin sulfate from cancer patients. A potential new marker for diagnosis of neoplasias." Lab Invest 68(4): 439-445.

Dietrich, C. P., et al. (1977). "Cell recognition and adhesiveness: a possible biological role for the sulfated mucopolysaccharides." Biochem Biophys Res Commun 75(2): 329-336.

Dietrich, C. P., et al. (1978). "Changes in the composition of sulfated mucopolysaccharides during neoplastic transformation of cerebral tissue." Cancer Res 38(11 Pt 1): 3969-3971.

Dimitrakov, J. and D. Guthrie (2009). "Genetics and phenotyping of urological chronic pelvic pain syndrome." J Urol 181(4): 1550-1557.

Erickson, D. R., et al. (1997). "Urinary chondroitin sulfates, heparan sulfate and total sulfated glycosaminoglycans in interstitial cystitis." J Urol 157(1): 61-64.

Erickson, D. R., et al. (2002). "A comparison of multiple urine markers for interstitial cystitis." J Urol 167(6): 2461-2469.

Esko, J. D. (1991). "Genetic analysis of proteoglycan structure, function and metabolism." Curr Opin Cell Biol 3(5): 805-816.

Evered, D. W., J. (1989). "The biology of hyaluronan." Ciba Found Symp 143: 1-298.

Fall, M., et al. (1985). "A clinicopathological and virological study of interstitial cystitis." J Urol 133(5): 771-773.

Forrest, J. B. and R. Moldwin (2008). "Diagnostic options for early identification and management of interstitial cystitis/painful bladder syndrome." Int J Clin Pract 62(12): 19261934.

Franco, C. R., et al. (2001). "Heparan sulfate and control of cell division: adhesion and proliferation of mutant CHO-745 cells lacking xylosyl transferase." Braz J Med Biol Res 34(8): 971-975.

Fraser, J. R., et al. (1997). "Hyaluronan: its nature, distribution, functions and turnover." J Intern Med 242(1): 27-33.

Gillenwater, J. Y. and A. J. Wein (1988). "Summary of the National Institute of Arthritis, Diabetes, Digestive and Kidney Diseases Workshop on Interstitial Cystitis, National Institutes of Health, Bethesda, Maryland, August 28-29, 1987." J Urol 140(1): 203-206. 
Girish, K. S. and K. Kemparaju (2007). "The magic glue hyaluronan and its eraser hyaluronidase: a biological overview." Life Sci 80(21): 1921-1943.

Hanno, P. and R. Dmochowski (2009). "Status of international consensus on interstitial cystitis/bladder pain syndrome/painful bladder syndrome: 2008 snapshot." Neurourol Urodyn 28(4): 274-286.

Hanno P, L. A., Nordling J, Nyberg A, von Ophen A, Ueda T (2009). Bladder Pain Syndrome. International consultation on incontinence. C. L. Abrams $P$, Khoury S, Wein A. Philadelphia, Health publication. 4th edition: 1461-1518.

Hanno P, L. A., Nordling J, Nyberg A, von Ophen A, Ueda T, Ed. (2009). Bladder pain syndrome international consultation on incontinence. Incontinence Book. Paris, Healht Publication LTD.

Hanno, P., et al. (2010). "Bladder Pain Syndrome Committee of the International Consultation on Incontinence." Neurourol Urodyn 29(1): 191-198.

Hanno, P., et al. (2008). "What is new in bladder pain syndrome/interstitial cystitis?" Curr Opin Urol 18(4): 353-358.

Hanno, P. M., et al. (2011). "AUA guideline for the diagnosis and treatment of interstitial cystitis/bladder pain syndrome." J Urol 185(6): 2162-2170.

Hanno, P. M., et al. (1999). "The diagnosis of interstitial cystitis revisited: lessons learned from the National Institutes of Health Interstitial Cystitis Database study." J Urol 161(2): 553-557.

Hanno, P. M. and G. R. Sant (2001). "Clinical highlights of the National Institute of Diabetes and Digestive and Kidney Diseases/Interstitial Cystitis Association scientific conference on interstitial cystitis." Urology 57(6 Suppl 1): 2-6.

Hauser, P. J., et al. (2008). "Abnormal expression of differentiation related proteins and proteoglycan core proteins in the urothelium of patients with interstitial cystitis." J Urol 179(2): 764-769.

Hohenfellner, M., et al. (1992). "Interstitial cystitis: increased sympathetic innervation and related neuropeptide synthesis." J Urol 147(3): 587-591.

Huang, C. L. and H. E. Ives (1987). "Growth inhibition by protein kinase C late in mitogenesis." Nature 329(6142): 849-850.

Hurst, R. E. (1994). "Structure, function, and pathology of proteoglycans and glycosaminoglycans in the urinary tract." World J Urol 12(1): 3-10. 
Hurst, R. E., et al. (1993). "Urinary glycosaminoglycan excretion as a laboratory marker in the diagnosis of interstitial cystitis." J Urol 149(1): 31-35.

Hurst, R. E., et al. (1996). "A deficit of chondroitin sulfate proteoglycans on the bladder uroepithelium in interstitial cystitis." Urology 48(5): 817-821.

Itano, N. and K. Kimata (2002). "Mammalian hyaluronan synthases." IUBMB Life 54(4): 195199.

Keay, S., et al. (2000). "Bladder epithelial cells from patients with interstitial cystitis produce an inhibitor of heparin-binding epidermal growth factor-like growth factor production." J Urol 164(6): 2112-2118.

Keay, S. and J. W. Warren (1998). "A hypothesis for the etiology of interstitial cystitis based upon inhibition of bladder epithelial repair." Med Hypotheses 51(1): 79-83.

Kjellen, L., et al. (1989). "Primary structure of a mouse mastocytoma proteoglycan core protein." Biochem J 263(1): 105-113.

Knudson, C. B. and W. Knudson (2001). "Cartilage proteoglycans." Semin Cell Dev Biol 12(2): 69-78.

Knudson, W., et al. (2002). "CD44-mediated uptake and degradation of hyaluronan." Matrix Biol 21(1): 15-23.

Kramer, M. W., et al. (2011). "Association of hyaluronic acid family members (HAS1, HAS2, and HYAL-1) with bladder cancer diagnosis and prognosis." Cancer 117(6): 1197-1209.

Laurent, C., et al. (1995). "Localization and quantity of hyaluronan in urogenital organs of male and female rats." Cell Tissue Res 279(2): 241-248.

Laurent, T. C. and J. R. Fraser (1986). "The properties and turnover of hyaluronan." Ciba Found Symp 124: 9-29.

Lilly, J. D. and C. L. Parsons (1990). "Bladder surface glycosaminoglycans is a human epithelial permeability barrier." Surg Gynecol Obstet 171(6): 493-496.

Lohmander, L. S., et al. (1980). "Oligosaccharides on proteoglycans from the swarm rat chondrosarcoma." J Biol Chem 255(13): 6084-6091. 
Lokeshwar, V. B., et al. (2005). "Urinary uronate and sulfated glycosaminoglycan levels:

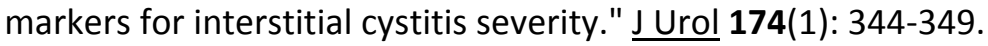

Lokeshwar, V. B., et al. (2006). "Uronate peaks and urinary hyaluronic acid levels correlate with interstitial cystitis severity." J Urol 176(3): 1001-1007.

Lynes, W. L., et al. (1987). "Mast cell involvement in interstitial cystitis." J Urol 138(4): 746-752.

Maroclo, M. V., et al. (2005). "Urinary glycosaminoglycan excretion during the menstrual cycle in normal young women." J Urol 173(5): 1789-1792.

Martins, J. R., et al. (2004). "Comparison of practical methods for urinary glycosaminoglycans and serum hyaluronan with clinical activity scores in patients with Graves' ophthalmopathy." Clin Endocrinol (Oxf) 60(6): 726-733.

Martins, J. R., et al. (2000). "Patients with head and neck tumors excrete a chondroitin sulfate with a low degree of sulfation: a new tool for diagnosis and follow-up of cancer therapy." Otolaryngol Head Neck Surg 122(1): 115-118.

Martins, J. R., et al. (2003). "Practical determination of hyaluronan by a new noncompetitive fluorescence-based assay on serum of normal and cirrhotic patients." Anal Biochem 319(1): 6572.

Mathews, M. B. (1975). "Connective tissue. Macromolecular structure and evolution." Mol Biol Biochem Biophys(19): 1-318.

Messing, E. M. and T. A. Stamey (1978). "Interstitial cystitis: early diagnosis, pathology, and treatment." Urology 12(4): 381-392.

Michelacci, Y. M., et al. (1979). "Chondroitin sulfates and proteoglycans from normal and arthrosic human cartilage." Connect Tissue Res 7(1): 29-36.

Morales, A., et al. (1997). "Intravesical hyaluronic acid in the treatment of refractory interstitial cystitis." Urology 49(5A Suppl): 111-113.

Mourao, P. A., et al. (1976). "The distribution of chondroitin sulfates in articular and growth cartilages of human bones." Biochim Biophys Acta 428(1): 19-26.

Nader, H. B., et al. (1984). "Isolation and structural studies of heparan sulfates and chondroitin sulfates from three species of molluscs." J Biol Chem 259(3): 1431-1435. 
Nader, H. B., et al. (2001). "Development of new heparin-like compounds and other antithrombotic drugs and their interaction with vascular endothelial cells." Braz J Med Biol Res 34(6): 699-709.

Nader, H. B., et al. (1982). "Selective appearance of heparin in mammalian tissues during development." Biochim Biophys Acta 714(2): 292-297.

Nickel, J. C., et al. (1998). "Relative efficacy of various exogenous glycosaminoglycans in providing a bladder surface permeability barrier." J Urol 160(2): 612-614.

Nickel, J. C., et al. (1993). "The bladder mucus (glycosaminoglycan) layer in interstitial cystitis." J Urol 149(4): 716-718.

Nilsson, B., et al. (1982). "Structures of N-linked and O-linked oligosaccharides on proteoglycan monomer isolated from the Swarm rat chondrosarcoma." J Biol Chem 257(18): 10920-10927.

Nogueira, M. D., et al. (1994). Hyaluronic acid, a characteristic glycosaminoglycan from ascitic fluids. XXIII Caxambu, MG.

Nusgens, B. V. (2010). "[Hyaluronic acid and extracellular matrix: a primitive molecule?]." Ann Dermatol Venereol 137 Suppl 1: S3-8.

O'Leary, M. P., et al. (1997). "The interstitial cystitis symptom index and problem index." Urology 49(5A Suppl): 58-63.

Oba-Shinjo, S. M., et al. (2003). "Decorin is one of the proteoglycans expressed in Walker 256 rat mammary carcinoma." Braz J Med Biol Res 36(8): 1079-1089.

Opal, S. M., et al. (2002). "Antithrombin, heparin, and heparan sulfate." Crit Care Med 30(5 Suppl): S325-331.

Pang, X., et al. (1995). "Increased number of substance $P$ positive nerve fibres in interstitial cystitis." Br J Urol 75(6): 744-750.

Parsons, C. L. (2007). "The role of the urinary epithelium in the pathogenesis of interstitial cystitis/prostatitis/urethritis." Urology 69(4 Suppl): 9-16.

Parsons, C. L. (2011). "The role of a leaky epithelium and potassium in the generation of bladder symptoms in interstitial cystitis/overactive bladder, urethral syndrome, prostatitis and gynaecological chronic pelvic pain." BJU Int 107(3): 370-375. 
Parsons, C. L., et al. (1985). "Inhibition of sodium urate crystal adherence to bladder surface by polysaccharide." J Urol 134(3): 614-616.

Parsons, C. L., et al. (1998). "The role of urinary potassium in the pathogenesis and diagnosis of interstitial cystitis." J Urol 159(6): 1862-1866; discussion 1866-1867.

Parsons, C. L., et al. (1977). "Role of surface mucin in primary antibacterial defense of bladder." Urology 9(1): 48-52.

Parsons, C. L., et al. (1975). "The primary antibacterial defense mechanism of the bladder." Invest Urol 13(1): 72-78.

Parsons, C. L. and R. E. Hurst (1990). "Decreased urinary uronic acid levels in individuals with interstitial cystitis." J Urol 143(4): 690-693.

Parsons, C. L., et al. (1991). "Epithelial dysfunction in nonbacterial cystitis (interstitial cystitis)." J Urol 145(4): 732-735.

Parsons, C. L., et al. (1983). "Successful treatment of interstitial cystitis with sodium pentosanpolysulfate." J Urol 130(1): 51-53.

Parsons, C. L., et al. (1980). "Bladder-surface glycosaminoglycans: an efficient mechanism of environmental adaptation." Science 208(4444): 605-607.

Perosa, S. R., et al. (2002). "Glycosaminoglycan levels and proteoglycan expression are altered in the hippocampus of patients with mesial temporal lobe epilepsy." Brain Res Bull 58(5): 509516.

Poblacion, C. A. and Y. M. Michelacci (1986). "Structural differences of dermatan sulfates from different origins." Carbohydr Res 147(1): 87-100.

Porcionatto, M. A., et al. (1998). "Stimulation of heparan sulfate proteoglycan synthesis and secretion during G1 phase induced by growth factors and PMA." J Cell Biochem 70(4): 563-572.

Porcionatto, M. A., et al. (1994). "Heparan sulfate proteoglycan and control of cell proliferation: enhanced synthesis induced by phorbol ester (PMA) during G(1)-phase." Braz J Med Biol Res 27(9): 2185-2190.

Rais-Bahrami, S., et al. (2012). "Symptom profile variability of interstitial cystitis/painful bladder syndrome by age." BJU Int 109(9): 1356-1359. 
Ramanathan, R., et al. (1996). "Alcohol inhibits cell-cell adhesion mediated by human L1." J Cell Biol 133(2): 381-390.

Sampaio, L. O., et al. (1988). "Dermatan sulphate proteoglycan from human articular cartilage. Variation in its content with age and its structural comparison with a small chondroitin sulphate proteoglycan from pig laryngeal cartilage." Biochem J 254(3): 757-764.

Sampaio, L. O. and C. P. Dietrich (1981). "Changes of sulfated mucopolysaccharides and mucopolysaccharidases during fetal development." J Biol Chem 256(17): 9205-9210.

Sampaio, L. O., et al. (1977). "Changes in sulfated mucopolysaccharide composition of mammalian tissues during growth and in cancer tissues." Biochim Biophys Acta 498(1): 123131.

Sant, G. R. and P. M. Hanno (2001). "Interstitial cystitis: current issues and controversies in diagnosis." Urology 57(6 Suppl 1): 82-88.

Schwalenberg, T., et al. (2011). "Enhanced urothelial expression of human chorionic gonadotropin beta (hCGbeta) in bladder pain syndrome/interstitial cystitis (BPS/IC)." World J Urol.

Scott, J. E. (1992). "Supramolecular organization of extracellular matrix glycosaminoglycans in vitro and in the tissues ., 6: 2639-2645, 1992." FASEB J 6: 2639-2645.

Scott, J. E. (2001). "Structure and function in extracellular matrices depend on interactions between anionic glycosaminoglycans." Pathol Biol 49(4): 284-289.

Shi, Y. and J. Massague (2003). "Mechanisms of TGF-beta signaling from cell membrane to the nucleus." Cell 113(6): 685-700.

Soler, R., et al. (2008). "Urine is necessary to provoke bladder inflammation in protamine sulfate induced urothelial injury." J Urol 180(4): 1527-1531.

Soler, R., et al. (2008). "Urinary glycosaminoglycans as biomarker for urothelial injury: is it possible to discriminate damage from recovery?" Urology 72(4): 937-942.

Soler, R., et al. (2006). The effect of DMSO on rat normal bladder mucosa and on bladder inflammation after protamine sulfate instillation. International Continence Society 36th Annual Meeting, Christchrurch, New Zealand.

Soler, R., et al. (2008). "Urinary glycosaminoglycans excretion and the effect of dimethyl sulfoxide in an experimental model of non-bacterial cystitis." Int Braz J Urol 34(4): 503-511; discussion 511. 
Soriano, E. S., et al. (2000). "Effect of epithelial debridement on glycosaminoglycan synthesis by human corneal explants." Clin Chim Acta 295(1-2): 41-62.

Theoharides, T. C., et al. (2001). "Mast cell involvement in interstitial cystitis: a review of human and experimental evidence." Urology 57(6 Suppl 1): 47-55.

Theoharides, T. C. and G. R. Sant (2005). "Immunomodulators for treatment of interstitial cystitis." Urology 65(4): 633-638.

Thonar, E. J. and M. B. Sweet (1979). "An oligosaccharide component in proteoglycans of articular cartilage." Biochim Biophys Acta 584(2): 353-357.

Tunitsky, E., et al. (2012). "Bladder pain syndrome/interstitial cystitis in twin sisters." J Urol 187(1): 148-152.

Van de Merwe, J. P., et al. (2008). "Diagnostic criteria, classification, and nomenclature for painful bladder syndrome/interstitial cystitis: an ESSIC proposal." Eur Urol 53(1): 60-67.

Warren, J. W., et al. (2004). "Prevalence of interstitial cystitis in first-degree relatives of patients with interstitial cystitis." Urology 63(1): 17-21.

Webster, D. C. and T. Brennan (1998). "Self-care effectiveness and health outcomes in women with interstitial cystitis: implications for mental health clinicians." Issues Ment Health Nurs 19(5): 495-519.

Wei, D. C., et al. (2000). "The association of elevated urinary total to sulfated glycosaminoglycan ratio and high molecular mass hyaluronic acid with interstitial cystitis." J Urol 163(5): 1577-1583. 